\title{
Mechanochemical synthesis of small organic molecules
}

\author{
Tapas Kumar Achar, Anima Bose and Prasenjit Mal
}

\author{
Review \\ Address: \\ School of Chemical Sciences, National Institute of Science Education \\ and Research (NISER) Bhubaneswar, HBNI, P.O. \\ Bhimpur-Padanpur, Via Jatni, Khurda 752050, Odisha, India \\ Email: \\ Prasenjit Mal ${ }^{*}$ - pmal@niser.ac.in \\ * Corresponding author \\ Keywords: \\ ball-milling; green chemistry; mechanochemistry; solid-phase \\ synthesis; solvent-free synthesis
}

\begin{abstract}
With the growing interest in renewable energy and global warming, it is important to minimize the usage of hazardous chemicals in both academic and industrial research, elimination of waste, and possibly recycle them to obtain better results in greener fashion. The studies under the area of mechanochemistry which cover the grinding chemistry to ball milling, sonication, etc. are certainly of interest to the researchers working on the development of green methodologies. In this review, a collection of examples on recent developments in organic bond formation reactions like carbon-carbon $(\mathrm{C}-\mathrm{C})$, carbon-nitrogen $(\mathrm{C}-\mathrm{N})$, carbon-oxygen $(\mathrm{C}-\mathrm{O})$, carbon-halogen $(\mathrm{C}-\mathrm{X})$, etc. is documented. Mechanochemical syntheses of heterocyclic rings, multicomponent reactions and organometallic molecules including their catalytic applications are also highlighted.
\end{abstract}

\section{Introduction}

The field of organic synthesis has experienced recently significant changes towards achieving the goal of more efficient and sustainable processes [1]. Thus, a new branch of chemistry termed as "Green Chemistry" has become a part of research interest by the chemists [2-4]. Green chemistry covers a wide range of research areas and generally deals with 12 principles $[5,6]$ and few of them are: avoiding the use of volatile and toxic solvents, reducing the quantity of catalyst and reagents, using environmentally benign chemicals, atom-economical synthesis, minimization of chemical-waste/energy, etc. Non-conventional energy sources for chemical reactions such as microwave, mechanical mixing, visible-light and ultrasound are becoming surge of interest to the chemist as alternative energy sources in laboratories [7]. By imposing these techniques innumerable chemical transformations have been documented and thereby developing many existing protocols with superior results are further anticipated $[8,9]$.

To address one of the major issues of green chemistry, i.e., minimizing chemical-waste/energy, solvent-free syntheses have become a popular research topic [8]. The mechanochemical techniques like ball-milling or hand grinding are considered to be promising candidates in solvent-free synthesis $[10,11]$. Mechanochemical methods deal with chemical transformations induced by mechanical energy, such as compression, shear, or friction [12]. Wilhelm Ostwald, a Russian-German chemist who 
received the Nobel Prize in 1909, mentioned the term "Mechanochemistry" as, like a branch of physical chemistry, i.e., thermochemistry, photochemistry and electrochemistry $[13,14]$. He defined the subject as "Mechanochemistry is a branch of chemistry which is concerned with chemical and physio-chemical changes of substances of all states of aggregation due to the influence of mechanical energy". Moreover, according to IUPAC, a mechano-chemical reaction is a "Chemical reaction that is induced by the direct absorption of mechanical energy' and with a note 'Shearing, stretching, and grinding are typical methods for the mechano-chemical generation of reactive sites, usually macroradicals, in polymer chains that undergo mechano-chemical reactions' [15].

The mechanistic understanding of mechanochemical reactions is still unclear [16]. A single idea could not be conceived because of the diversified nature of the reactions being practiced under mechanochemistry. Among the proposed models "hot spot" and "magma-plasma model" are mostly acceptable $[17,18]$. Other models like spherical model, dislocation and phonon theory, short-live-active center theory, kinetic and impulse model are also well known [19,20]. Nevertheless, this subject needs more attention to the both experimental and theoretical chemists [21].

The sophisticated technique of ball-milling or mechanomilling is the adaptation from the traditional grinding methods using a mortar and pestle. These mechanomillings methods are generally conducted in vibration mills or planetary mills at frequencies of 5-60 Hz [22,23]. The extensively used mechanomilling technique has limitations in controlling the reactions for air- and moisture-sensitive substances. In mechanomilling methods generally, the reactions are carried out in sealed vessels or jars of materials like stainless steel, tungsten carbide, zirconia, agate, etc. [24].

In the past decade, mechanochemical reactions were developed under the areas of chemistry like supramolecular chemistry $[25,26]$, organic synthesis $[27,28]$, nanoparticle synthesis, etc. $[29,30]$. The historical development of mechanochemistry [31], mechanistic aspects [32], mechanochemical synthesis of inorganic material [33], co-crystals [34], metal-ligand complexes [35], metal organic frameworks [36], polymers [37], etc. are well documented in seminal reviews and will not be discussed here. The organic mechanochemistry has remained undeveloped until the pioneering work reported by Toda in the 1980s [38] and Kaupp [24]. Due to several advantages, the area mechanochemistry has received significant attention over solution-based chemical methods and process developments $[12,27,29]$. The mechanochemical formation of carbon-carbon $[39,40]$, carbon-heteroatom $[41,42]$, metal-ligand coordination bonds [43], non-covalent interactions such as hydrogen bonds or $\pi-\pi$ arene stacking interactions [44], etc. are popularly known in literature. In this review the efforts are given towards documentation of various mechanochemical reactions like organic bond formation reactions, multicomponent reactions, heterocyclic ring synthesis, synthesis of organometallic complexes and their catalytic applications, and so on.

\section{Review}

\section{Mechanochemical organic synthesis}

Famous philosopher Aristotle's statement "No Coopora nisi Fluida" means "no reaction is possible in the absence of solvent' and that was a common belief till last few decades. However, during the 1980s the pioneering works of Toda and co-workers proved that many organic reactions of solution chemistry would be reproducible in solid state too [22,23]. In the solid state reactions the ingredients are mixed to finely powdered form for better mixing. The ball-milling chemistry can better be conceived as the updated and sophisticated version of traditional grinding chemistry [38].

\section{Mechanochemical synthesis of $\mathrm{C}-\mathrm{C}$ bond}

More atom economic, energy efficient, time efficient and mild syntheses of $\mathrm{C}-\mathrm{C}$ bonds are always desired. The solvent-free mechanomilling technique can also be an important alternative to replace traditional hand grinding methods [45]. Many solution-based $\mathrm{C}-\mathrm{C}$ bond synthesis methods are reproducible under mechanomilling conditions with improved time and energy efficiency $[46,47]$. In this section some of the most important $\mathrm{C}-\mathrm{C}$ bond forming reactions and their advantages are discussed.

\section{Aldol reaction}

In 2000, Raston and Scott first reported the aldol condensation reaction using veratraldehyde, 4-phenylcyclohexanone and 1-indanone in the presence of $\mathrm{NaOH}$ in a vibrating ball mill and the products were obtained in the yield up to $98 \%$ within $10 \mathrm{~min}$ (Scheme 1) [48].

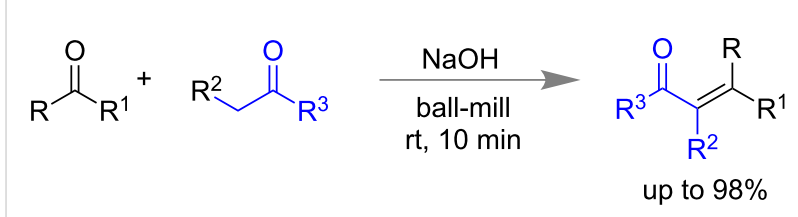

Scheme 1: Mechanochemical aldol condensation reactions [48].

However, the asymmetric version of a mechanochemical aldol condensation reaction was reported by Guillena and Nájera with co-workers (Scheme 2a) in 2008. Reactions between various ketones and aldehydes under solvent-free conditions were per- 
a)<smiles></smiles>
(anti/syn 69:31; ee 88\%) b)

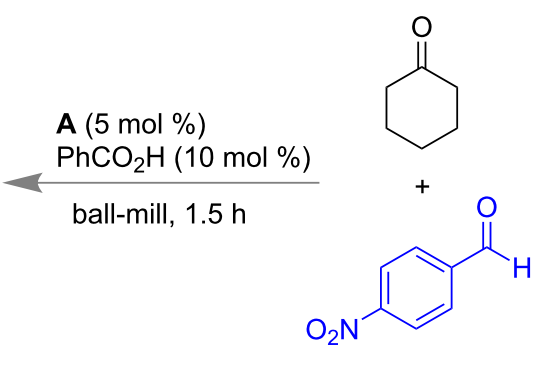

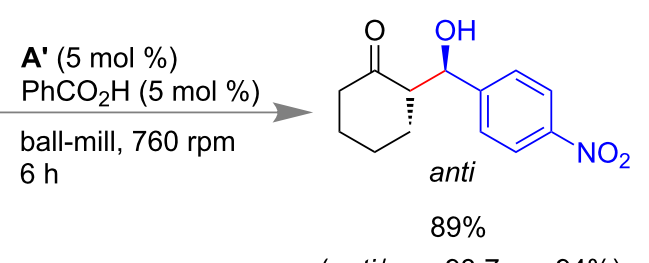

(anti/syn 93:7; ee 94\%)

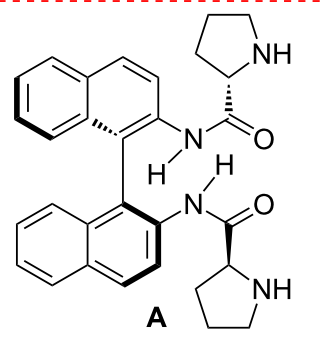

binam-(S)-proline derived catalyst

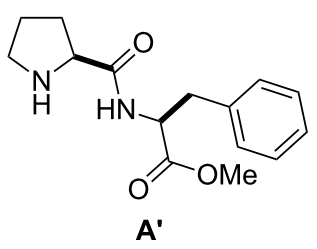

$(S, S)$-dipeptide based catalyst

Scheme 2: Enantioselective organocatalyzed aldol reactions under mechanomilling. a) Based on binam-(S)-proline derived catalyst [49]. b) Report using a,a-dipeptide-based catalyst [50].

formed using a combination of (S)-binam-L-Pro (A, $5 \mathrm{~mol} \%)$ and benzoic acid (10 $\mathrm{mol} \%)$ as organocatalyst [49].

Juaristi and co-workers investigated the mechanistic aspects of $\alpha, \alpha$-dipeptide derivatives of a $(S)$-proline- $\left(\mathbf{A}^{\prime}\right)$-catalyzed asymmetric aldol reaction (Scheme $2 b$ ) under solvent-free mechanomilling [50]. By varying the electron density on the aromatic aldehydes, it was observed that electron deficient aldehydes provided a better yield with excellent stereo selectivity over electron rich systems. The observed result suggests that a $\pi-\pi$ stacking interaction between electron-poor aromatic aldehydes and aromatic ring of the organocatalyst plays a crucial role for excellent yield and selectivity. Apparently the solvent-free system enhances the rigidity of the transition state for more selective reactions under mechanochemical activation.

\section{Michael addition}

Generally strong bases like $\mathrm{NaOH}, \mathrm{KOH}, \mathrm{NaOEt}$ etc. have been used as catalyst for the Michael addition of 1,3-dicarbonyl compounds to $\alpha, \beta$-unsaturated ketones. In 2004, Wang and co-workers first reported a mechanochemical Michael reaction of 1,3-dicarbonyl compounds with chalcones and azachalcones using the mild base $\mathrm{K}_{2} \mathrm{CO}_{3}$ (Scheme 3). Michael adducts were isolated with good to excellent yield (76-99\%) in a high-speed vibration mill (HSVM) within 10-60 $\min [51]$.

Bolm and co-workers reported an organocatalytic asymmetric version of Michael addition reaction under planetary-milling (PM) conditions. Differently substituted thiourea-based organocatalysts were screened for the reaction to achieve stereoselective adducts through hydrogen bonding. Only with $2.5 \mathrm{~mol} \%$ of thiourea-based catalyst $\mathbf{B}, \alpha$-nitrocyclohexanone and nitroalkene derivatives could undergo a Michael addition to yield up to $95 \%$ of the desired product within $30 \mathrm{~min}$ (Scheme 4). Excellent stereoselectivity was also achieved with a diastereomeric ratio of 98:2 and enantiomeric ratio up to 99:1. Simple flash column chromatographic purification methods, low catalyst loading,

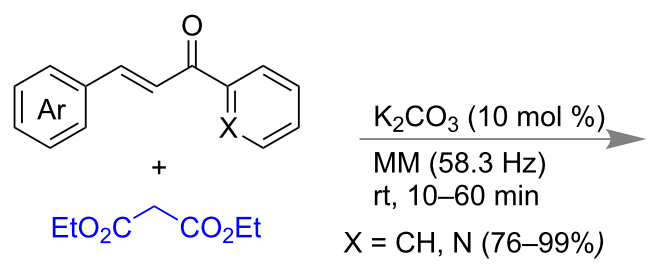<smiles>[X]c1ccccc1C(=O)C[C@@H](c1ccccc1)[C@@H](COCC)C(=O)OCC</smiles><smiles>[X]c1ccccc1C(=O)C[C@@H](c1ccccc1)C(C(=O)OCC)C(=O)OCC</smiles> 

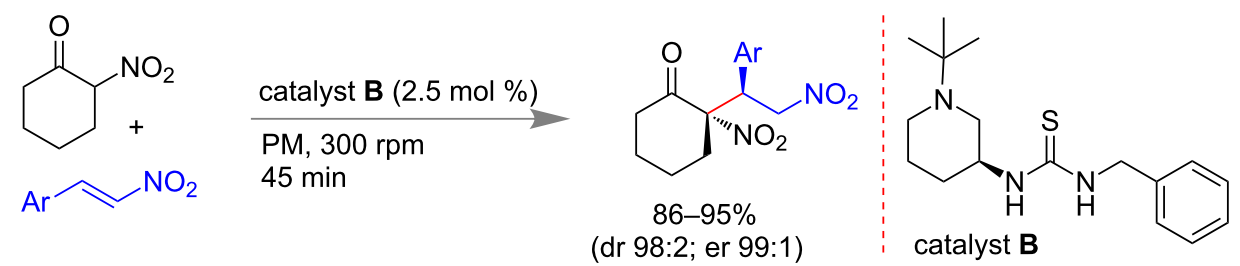

Scheme 4: Mechanochemical organocatalytic asymmetric Michael reaction [52].

gram scale synthesis, etc. were advantageous for the reaction [52].

\section{Morita-Baylis-Hillman reaction}

The Morita-Baylis-Hillman reaction (MBH) employs olefins, tertiary amine catalysts and electrophile aldehydes to produce multifunctional products. Mack et al., found a significant enhancement in the rate of a Morita-Baylis-Hillman (MBH) reaction under ball milling conditions (Scheme 5) compared to the conventional method that generally takes days to a week for completion. The reaction of methyl acrylate with different parasubstituted aryl aldehydes in the presence of $20 \mathrm{~mol} \% 1,4-$

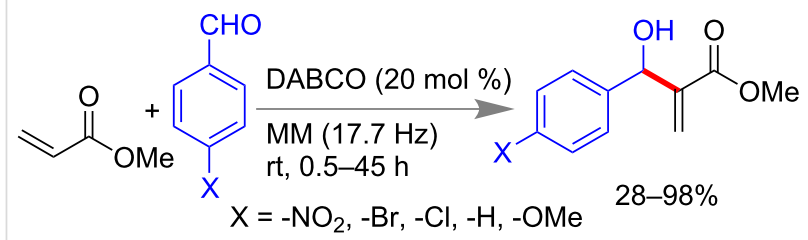

Scheme 5: Mechanochemical Morita-Baylis-Hillman (MBH) reaction [53]. diazabicyclo[2.2.2] octane (DABCO) catalyst at $0.5-45 \mathrm{~h}$ yielded the $\mathrm{MBH}$ products in $28-98 \%$ yield [53].

\section{Wittig Reaction}

Pecharsky and co-workers reported the solvent-free mechanochemical synthesis of phosphonium salts [54] and phosphorus ylides [55] in the presence of the weak base $\mathrm{K}_{2} \mathrm{CO}_{3}$. Mechanochemically prepared phosphorous ylide from triphenylphosphine in presence of $\mathrm{K}_{2} \mathrm{CO}_{3}$ was utilized for a onepot solvent-free Wittig reaction of organic halides with aldehydes or ketones (Scheme 6) [55].

\section{Suzuki Coupling}

In 2000, Peters and co-workers first reported the palladium-catalyzed Suzuki coupling reaction under ball-milling conditions [56]. In a planetary mill for 30-60 min, the mixture of aryl halide (1.0 equiv), phenylboronic acid (2.0 equiv), $\mathrm{K}_{2} \mathrm{CO}_{3}$ (3.0 equiv) and $\mathrm{Pd}\left(\mathrm{PPh}_{3}\right)_{4}(5 \mathrm{~mol} \%)$ resulted in coupled products with $96 \%$ yield (Scheme 7 ). The $\mathrm{NaCl}$ was used as an additive to make the reaction mixture sufficiently powdery for uniform mixing.
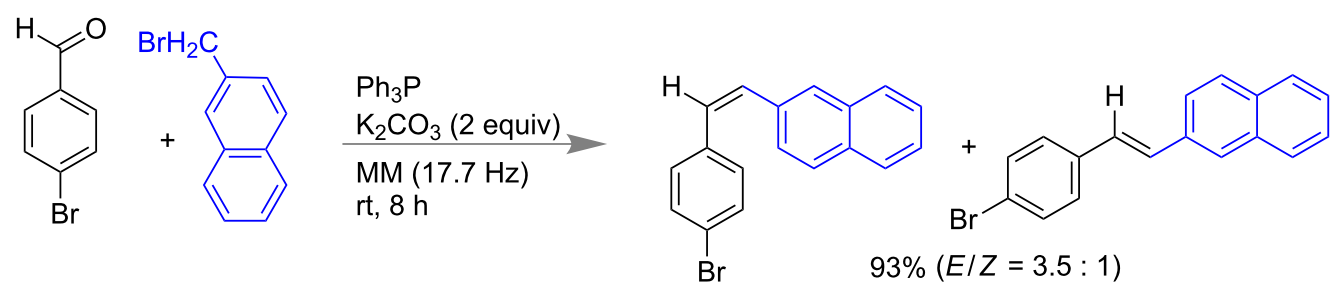

Scheme 6: Mechanochemical Wittig reactions [55].
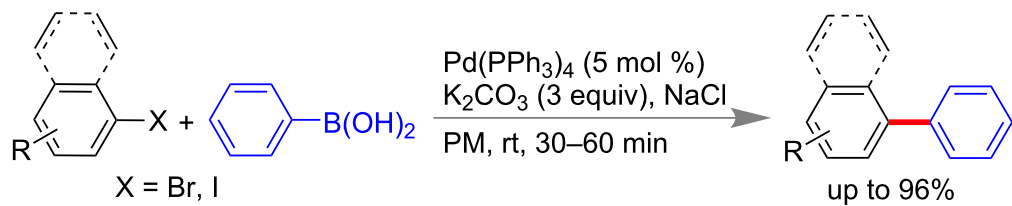

Scheme 7: Mechanochemical Suzuki reaction [56]. 
The use of aryl chlorides is generally restricted in Suzuki reactions because of their low reactivity. Recently, $\mathrm{Li}$ and $\mathrm{Su}$ with co-workers have developed a liquid-assisted grinding (LAG) method for the Suzuki-Miyaura coupling between aryl chlorides and boronic acids to synthesize the biaryls in nearly quantitative yield. Under optimized conditions $2 \mathrm{~mol} \%$ $\mathrm{Pd}(\mathrm{OAc})_{2}$ and $4 \mathrm{~mol} \%$ of $\mathrm{PCy}_{3} \cdot \mathrm{HBF}_{4}$ along with an excess $\mathrm{K}_{2} \mathrm{CO}_{3}-\mathrm{MeOH}$ led to biaryls within 99 min and with a yield up to $97 \%$ (Scheme 8 ) [57].

\section{Heck reaction}

Frejd and co-workers reported the first mechanochemical Heck reaction [58]. Su and co-workers demonstrated that $(E)$-stilbene derivatives were synthesized by the coupling of styrenes with aryl bromides or aryl chlorides (Scheme 9) [59].

\section{Sonogashira reaction}

Stolle and co-workers have reported a Sonogashira coupling reaction under ball milling conditions in which the reactions were done in absence of any copper catalyst or any additional ligands [60]. In presence of palladium salts $\left(\mathrm{Pd}(\mathrm{OAc})_{2}\right.$ or $\left.\mathrm{Pd}\left(\mathrm{PPh}_{3}\right)_{4}\right)$ and DABCO (1,4-diazabicyclo[2.2.2] octane) various acetylenes and aryl halides were coupled to obtain the Sonogashira coupling products in excellent yields (near quantitative, Scheme 10a). The reactions were reported for aliphatic alkynes as well. In Scheme 10b, an example of a double Sonogashira reaction is shown [60].

\section{Oxidative cross-dehydrogenative coupling}

Copper-catalyzed mechanochemical oxidative cross-dehydrogenative coupling (CDC) reactions [61-66] of tetrahydroisoquinolines with alkynes and indoles was reported by $\mathrm{Su}$ and co-workers (Scheme 11) using 2,3-dichloro-5,6-dicyanoquinone (DDQ) as an efficient oxidant [67].

$\mathrm{Su}$ and co-workers have also reported an asymmetric version of the $\mathrm{CDC}$ reaction between terminal alkynes and $\mathrm{sp}^{3} \mathrm{C}-\mathrm{H}$ bonds under high speed ball milling conditions [68]. Several optically
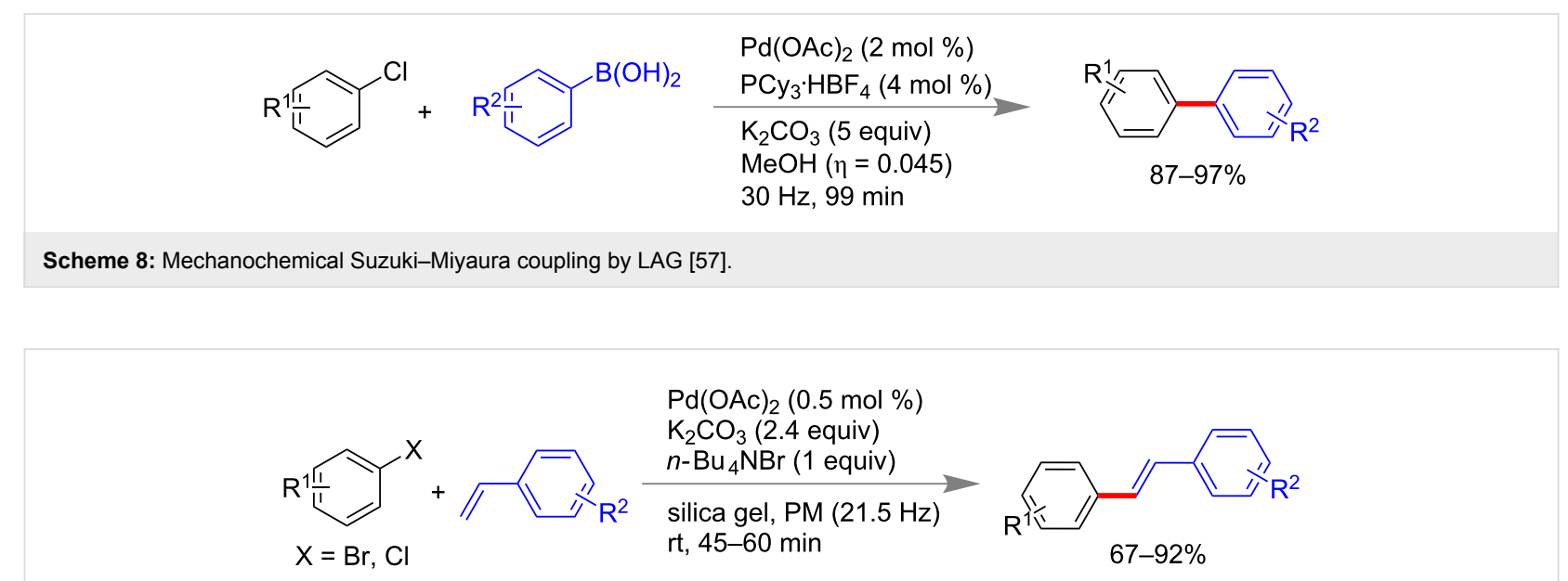

Scheme 9: Mechanochemical Heck reaction [59].

a)<smiles>[X]C#Cc1ccc[R]([R])c1</smiles>

$\mathrm{X}=\mathrm{Br}, \mathrm{I}$

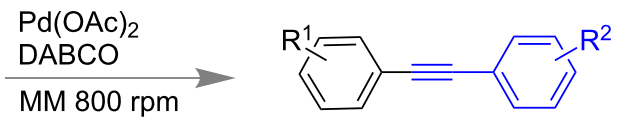

up to $99 \%$

b)

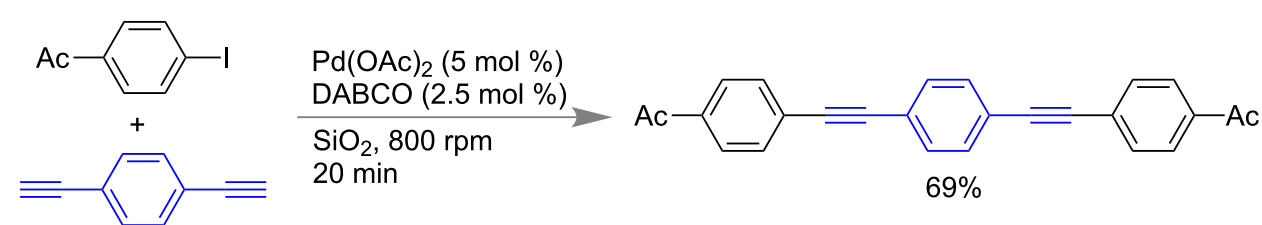

Scheme 10: a) Sonogashira coupling under milling conditions. b) The representative example of a double Sonogashira reaction of $p$-iodoacetophenone with 1,4-bis-ethynyl benzene. 
a) CDC of indole and tetrahydro-isoquinoline<smiles>[R]c1ccc2c(c1)cc([R])n2[R2]</smiles><smiles>[R]c1ccc2[nH]c([R])c(C3c4ccccc4CCN3[Y])c2c1</smiles>

up to $80 \%$ b) CDC of alkyne and tetrahydro-isoquinoline

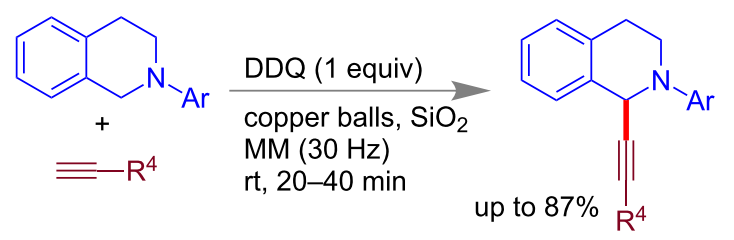

Scheme 11: Copper-catalyzed CDC reaction under mechanomilling [67].

active 1-alkynyl tetrahydroisoquinoline derivatives were synthesized using a pyridine-based chiral ligand (PyBox, Scheme 12) in the presence of DDQ (2,3-dichloro-5,6-dicyano1,4-benzoquinone). The coupling products were isolated in fair yields with ee's (enantiomeric excesses) up to 79\%. The milling copper balls were also identified as reacting catalyst.

$\mathrm{Su}$ and co-workers reported an $\mathrm{Fe}$ (III)-catalyzed coupling of 3-benzyl indoles with molecules having active methylene group under solvent-free ball-mill in presence of silica gel as milling auxiliary. Using $10 \mathrm{~mol} \% \mathrm{Fe}\left(\mathrm{NO}_{3}\right)_{3} \cdot 9 \mathrm{H}_{2} \mathrm{O}$ as catalyst and 1.0 equiv of DDQ afforded good yield of desired product at $25 \mathrm{~Hz}$ within $30 \mathrm{~min}$ (Scheme 13) [69]. The oxidant DDQ was added in portions at $7 \mathrm{~min}$ intervals to get better yields. Different active methylene compounds like diethylmalonate, dibenzylmalonate, malonitrile, and unsymmetrical 1,3-dicarbonyl compounds were explored for the CDC reaction.

They have also demonstrated a mechanochemical synthesis of 3 -vinylindoles and $\beta, \beta$-diindolylpropionates by $\mathrm{C}-\mathrm{H}$ activation. Substituted indoles and ethyl acrylates were reacted in presence of $10 \mathrm{~mol} \%$ of $\mathrm{Pd}(\mathrm{OAc})_{2}$ and 1.2 equiv of $\mathrm{MnO}_{2}$ to afford highly substituted 3-vinylindoles using silica gel and acetic acid (LAG). Contrastingly, when acrylic esters were treated with $8 \mathrm{~mol} \%$ of $\mathrm{PdCl}_{2}$ and in absence of acetic acid, $\beta, \beta$-diindolylpropionates were obtained as the major product (Scheme 14) [70].

\section{$\mathrm{C}-\mathrm{N}$ bond synthesis}

Amongst $\mathrm{C}-\mathrm{N}$ bonds the amide bonds are most abundant and important too [71]. According to the American Chemical Society (ACS) and the Green Chemistry Institute (GCI), the "amide bond formation avoiding poor atom economy reagent" is one of the top challenges for organic chemists [72]. Easy, economical, selective and convenient approaches on $\mathrm{C}-\mathrm{N}$ bond syntheses are of great importance [73-76]. In view of this, chemists have introduced alternative energy sources like, microwave, sonication, mechanomilling, etc. [12,27,77]. Su and co-workers reported a copper-catalyzed arylation of anilines using arylboronic acid under high speed ball-milling conditions. Using 1.0 equiv of $\mathrm{Cu}(\mathrm{OAc})_{2}$ and 2.5 equiv of $\mathrm{K}_{2} \mathrm{CO}_{3}$ and in<smiles></smiles>

$+$ $\equiv-\mathrm{Ph}$

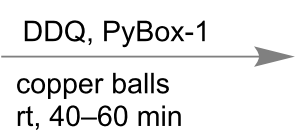

rt, 40-60 min

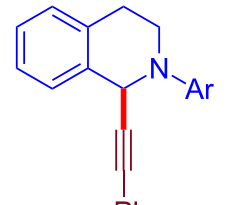

$\mathrm{Ph}$

up to $79 \%$ ee

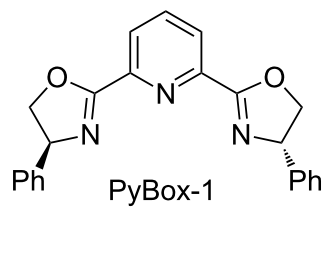

Scheme 12: Asymmetric alkynylation of prochiral $\mathrm{sp}^{3} \mathrm{C}-\mathrm{H}$ bonds via $\mathrm{CDC}$ [68].

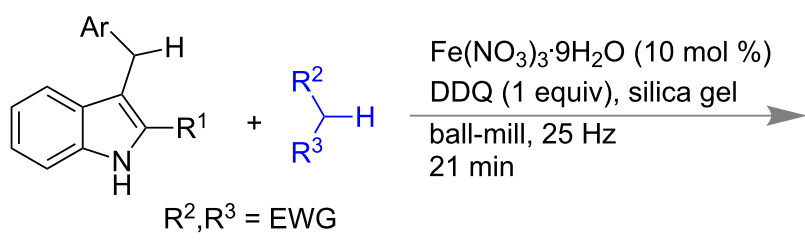

$\mathrm{R}^{2}, \mathrm{R}^{3}=\mathrm{EWG}$<smiles>[R]c1[nH]c2ccccc2c1C([Al])C([R])[R]</smiles>

up to $95 \%$ 


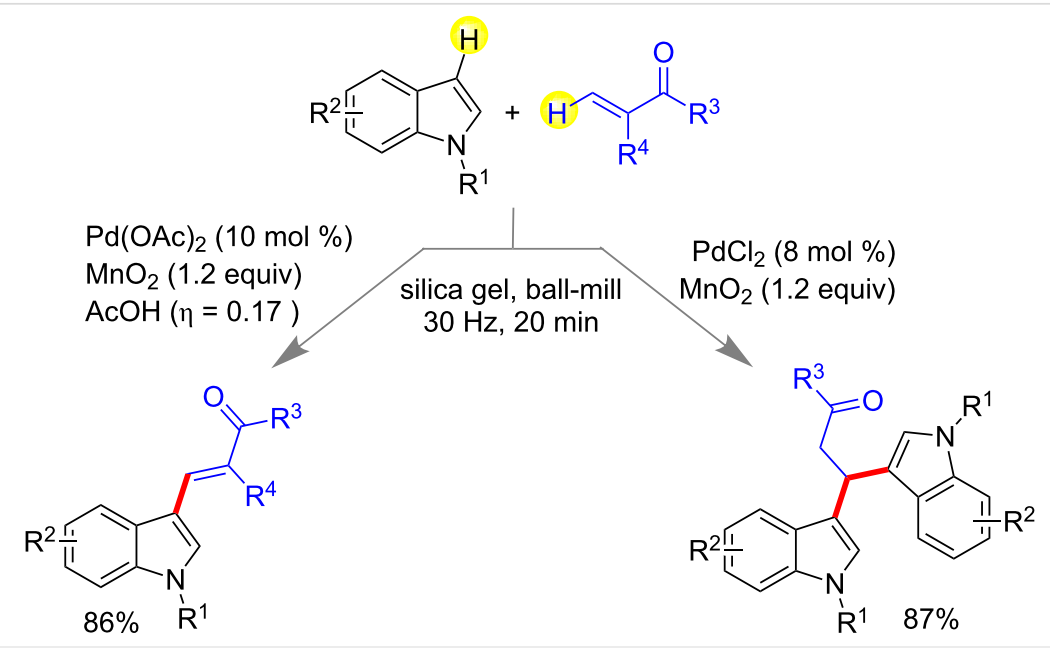

Scheme 14: Mechanochemical synthesis of 3-vinylindoles and $\beta, \beta$-diindolylpropionates [70].

the presence of milling auxiliary silica gel, differently substituted arylboronic acid and anilines led to $N$-arylated products in $58-86 \%$ yield (Scheme 15) [78]. They have also explored the reactivity of other amines like alkyl, primary, secondary, heterocyclic, etc.

Mal and co-workers reported a metal free, solvent-free and room temperature synthesis of amide bonds at $62-75 \%$ yield under ball-milling $(21 \mathrm{~Hz})$ from aromatic aldehydes and $\mathrm{N}$-chloramine in presence of $20 \mathrm{~mol} \%$ of tetrabutylammonium iodide (TBAI) and 2.0 equiv of TBHP (Scheme 16) [79]. Aromatic aldehydes having electron-donating or -withdrawing substituents and different $N$-chloramines were well tolerated for this moderately yielding reaction.

They have also reported a method of controlling the chemical reactivity of contact explosives by exploiting weak interactions or soft force [80] during amide bond synthesis under ballmilling conditions. Cross dehydrogenative coupling reactions between benzaldehydes and benzylamines were performed in presence of phenyliodine diacetate (PIDA) using the acid salt $\mathrm{NaHSO}_{4}$ [81]. The highly exergonic reaction (contact explosive) of acidic iodine(III) and basic amines were safely controlled at maximum contacts (solvent-free) by the acid salt $\mathrm{NaHSO}_{4}$. Using 2.0 equiv of both $\mathrm{NaHSO}_{4}$ and PIDA, 72-92\% of amides were isolated within $2 \mathrm{~h}$ (Scheme 17) [81].

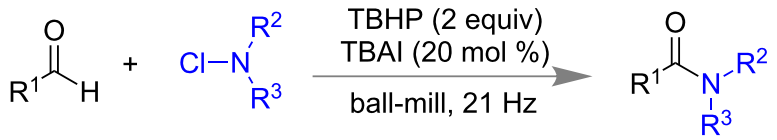

$$
\begin{aligned}
& 62-75 \%
\end{aligned}
$$

Scheme 16: Mechanochemical amidation reaction from aromatic aldehydes and $\mathrm{N}$-chloramine [79].

Amino acids are one of the important biomolecules for example as building block of peptides and proteins [75,82-84]. During the synthetic application of these molecules protection of $-\mathrm{NH}_{2}$ and $-\mathrm{COOH}$ group are needed. The traditional protection chemistry involves hazardous solvents, direct handling of corrosive reagents, longer reaction time, and tedious purification processes, etc. Therefore, methodologies involving mild reaction conditions, simple purification processes are always desirable. In 2014, Colacino and co-workers reported the protection of $-\mathrm{NH}_{2}$ and $-\mathrm{COOH}$ groups of amino acids by solvent-free milling methods using two different conditions [85]: 1) carbamoylation of amino esters using Fmoc- $\mathrm{Cl}$ and $\mathrm{NaHCO}_{3}$ (base); 2) esterification of $\mathrm{N}$-protected amino acid using different dialkyl dicarbonate or alkyl chloroformate in the presence of DMAP as catalyst and followed by acidic workup. For $\mathrm{N}$-terminal protection, different precursors like Fmoc-Cl, benzoyl chloride and $\mathrm{Boc}_{2} \mathrm{O}$ were used successfully to get nearly $90 \%$ yields for $\alpha$-amino esters in 90-120 $\mathrm{min}$ (Scheme 18).

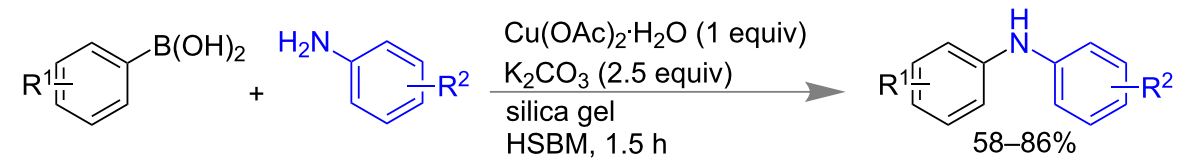




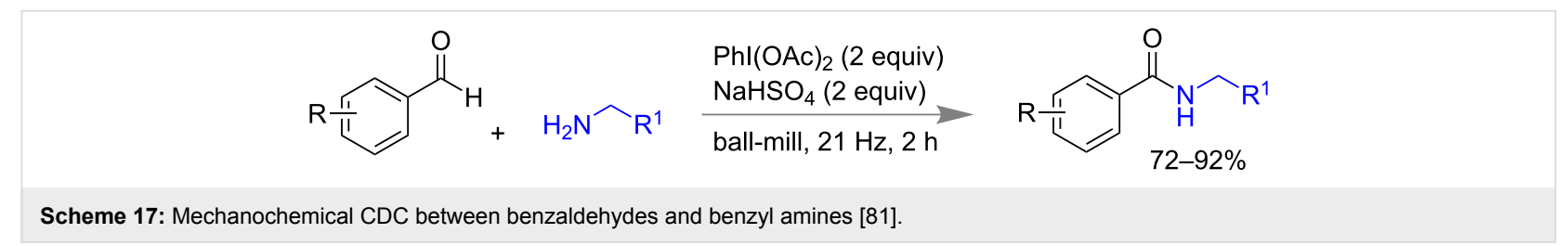

a) $\mathrm{N}$-protection of amino esters<smiles>[X][M]C([R])C(=O)O[R]</smiles>

b) C-protection of $\mathrm{N}$-protected amino acid

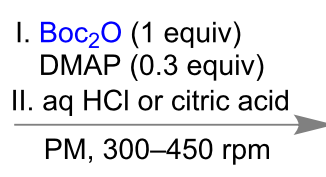

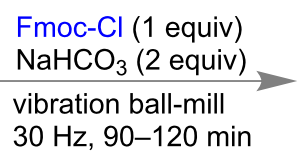

$30 \mathrm{~Hz}, 90-120 \mathrm{~min}$
Fmoc $\overbrace{\mathrm{O}}^{\mathrm{R}^{1}} \mathrm{OR}^{2}$<smiles>O=C(Cl)OCC1c2ccccc2-c2ccccc21</smiles>

$\mathrm{Fmoc}-\mathrm{Cl}$<smiles>[R]NC([R])C(=O)O</smiles><smiles>[R]NC([R1])C(=O)O[R6]</smiles>

Scheme 18: Mechanochemical protection of $-\mathrm{NH}_{2}$ and $-\mathrm{COOH}$ group of amino acids [85].

The Ritter reaction is another significant carbon-nitrogen $(\mathrm{C}-\mathrm{N})$ bond forming reaction in the synthesis of amides [86]. Generally, a nitrile and a tertiary alcohol in presence of a strong acid react to create amides. Major drawbacks associated with this method are the requirement of stoichiometric amounts of strong acid, higher temperature, narrower substrate scope, etc. In 2015, Gredičak and co-workers developed a milder version of the Ritter reaction under mechanomilling conditions. Using 0.5 equivalents of $\mathrm{H}_{2} \mathrm{SO}_{4}$, amides were isolated in good yields within $30 \mathrm{~min}$ of reaction time (Scheme 19) [87]. Various aromatic and aliphatic nitriles including acetonitrile, alcohols like tert-butanol and other secondary alcohols were used for this reaction. In case of solid nitriles 1.0 equiv of nitromethane was added during the grinding process to stabilize the carbocation species. This method was proved to be efficient by performing the reaction at $9.7 \mathrm{mmol}$ scale to obtain $84 \%$ yield of the product.

$$
\mathrm{R}^{1}-\mathrm{CN}+\mathrm{R}^{2}-\mathrm{OH} \frac{\mathrm{H}_{2} \mathrm{SO}_{4}(0.5 \text { equiv) }}{\begin{array}{l}
\text { ball-mill, WC ball } \\
30 \mathrm{~Hz}, 30 \text { min }
\end{array}} \underset{\text { up to } 94 \%}{\mathrm{R}^{1}}
$$

Scheme 19: Mechanochemical Ritter reaction [87].

\section{$\mathrm{C}-\mathrm{O}$ bond formation reaction}

Carbon-oxygen $(\mathrm{C}-\mathrm{O})$ bonds are widely present in molecules containing ester, carbamate and amino acid, etc. [88]. Tradi- tional solution-based $\mathrm{C}-\mathrm{O}$ bond synthesis generally needs large amount of solvents, excess chlorinating agent, harsh reaction conditions, a tedious isolation process, etc. compared to solvent-less grinding or mechanomilling [89]. In 2011, Mack and co-workers applied the high-speed ball milling (HSBM) technique for the synthesis of dialkyl carbonates [90]. Using potassium carbonate, alkyl halide and 2 equiv of phase-transfer catalyst 18 -crown-6 yielded dialkyl carbonate in $74 \%$. However, in absence of 18 -crown- 6 the yield was only $2 \%$ at $17 \mathrm{~h}$ (Scheme 20).

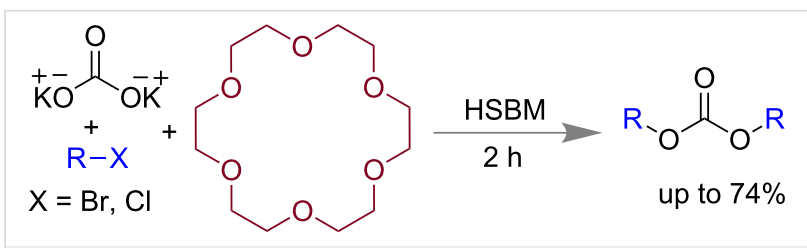

Scheme 20: Mechanochemical synthesis of dialkyl carbonates [90].

Transesterification is a synthetic approach mostly being used for making higher homologous esters from the simpler ones. Ranu and co-workers developed simple method for transesterification under mechanomilling [91]. The mixture of ester and alcohols were adsorbed on the surface of basic alumina and followed by milling of the materials for $2-3 \mathrm{~h}$ led to $65-81 \%$ of trans-esterified product (Scheme 21). Differently substituted benzene rings including hetero-aromatics were also well tolerated under the similar condition. 


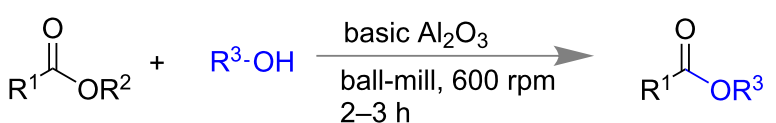

$$
\begin{aligned}
& \text { 65-81\% }
\end{aligned}
$$

Scheme 21: Mechanochemical transesterification reaction using basic $\mathrm{Al}_{2} \mathrm{O}_{3}$ [91].

Colacino and co-workers reported the preparation of carbamates by using 1,1'-carbonyldiimidazole (CDI) and in presence of either alcohols or amines as nucleophile [92]. When 2 equiv of CDI was treated with alcohol in a mixer mill at $30 \mathrm{~Hz}$, within 15 min imidazolecarboxylic acid derivatives were isolated with a new $\mathrm{C}-\mathrm{O}$ bond formation (Scheme 22).

$$
\text { ball-mill, } 30 \mathrm{~Hz}
$$

Scheme 22: Mechanochemical carbamate synthesis [92].

\section{C-X bond forming reactions}

Carbon-halogen $(\mathrm{C}-\mathrm{X})$ bond forming reactions are also significant in organic synthesis because aryl halides are important synthons for the synthesis of many natural and non-natural products [93,94]. In 2005, Rahman and co-workers reported a pioneering solid state benzylic bromination of diquinoline derivatives via $N$-bromosuccinimide (NBS) [95]. In 2012, Wang and co-workers reported bromination of phenol derivatives, chalcones, 1,3-dicarbonyl compounds using $\mathrm{NaBr}$ as bromine source and oxone as oxidant under ball-milling conditions [96]. Within $1 \mathrm{~h}$ they could isolate more than $90 \%$ of mono or polybrominated products of phenol and 1,3-dicarbonyl compounds (Scheme 23). $\alpha, \beta$-Unsaturated carbonyl compounds could also undergo a trans-bromination reaction efficiently within $40 \mathrm{~min}$.

Following to Wang's report, Stolle and co-workers also reported a similar method of aryl bromination and chlorination using $\mathrm{NaBr}$ and $\mathrm{NaCl}$, respectively, in the presence of oxidizing agent oxone (Scheme 24) [97].

Carbon-carbon double $(\mathrm{C}=\mathrm{C})$ and triple $(\mathrm{C} \equiv \mathrm{C})$ bonds-containing compounds are also reported to undergo dihalogenation reactions under mechanochemical conditions. In 2014, Mal and co-workers reported a mild aryl halogenation reaction using respective $N$-halosuccinimide (NXS) under solvent-free ball milling condition [88]. Aryl rings containing electron donating groups worked efficiently to yield $70-98 \%$ of mono or dibromo derivatives within $2 \mathrm{~h}$. Similarly, NIS led to aryl iodination in a) bromination of 1,3-dicarbonyl compounds<smiles>[R]C(=O)CC([R])=O</smiles>

b) bromination of phenol derivatives

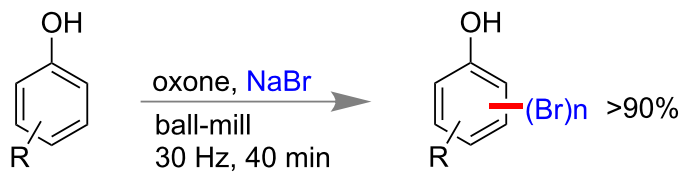

c) bromination of $\alpha, \beta$-unsaturated molecules

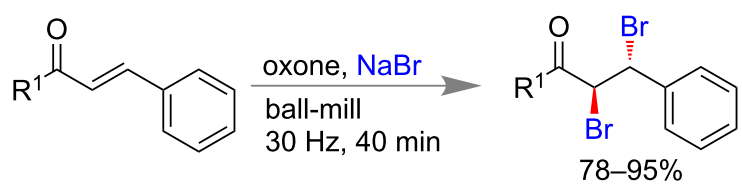

Scheme 23: Mechanochemical bromination reaction using $\mathrm{NaBr}$ and oxone [96].

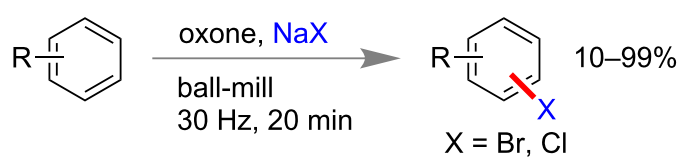

Scheme 24: Mechanochemical aryl halogenation reactions using $\mathrm{NaX}$ and oxone [97].

near quantitative yield and NCS failed to produce any chlorination product (Scheme 25). However, NCS-cericammonium nitrate (CAN) successfully yielded mono-chlorinated products [88]. Consecutively, the same group reported metal-free oxidative iodination of electron rich aromatic rings with molecular iodine and oxone (Scheme 25) [98]. This method proved to be highly chemoselective and no benzylic iodination could be observed in case of alkyl benzenes. Interestingly, benzaldehyde derivatives did not lead to any over-oxidation to acids in presence of oxone.

Trihaloisocyanuric acids are also used effectively for halogenations of arenes and 1,3-dicarbonyl compounds and double bond-containing systems [99]. Moorthy and co-workers investigated the potential of tribromoisocyanuric acid (TBCA) and trichloroisocyanuric acid (TCCA) under a solvent-free mechanomilling system for halogenations of electron rich arenes. The reactions were found to have yields above $80 \%$ for most of the cases but with poor selectivity in mono- or polybrominations (Scheme 26). They have also explored halogena- 


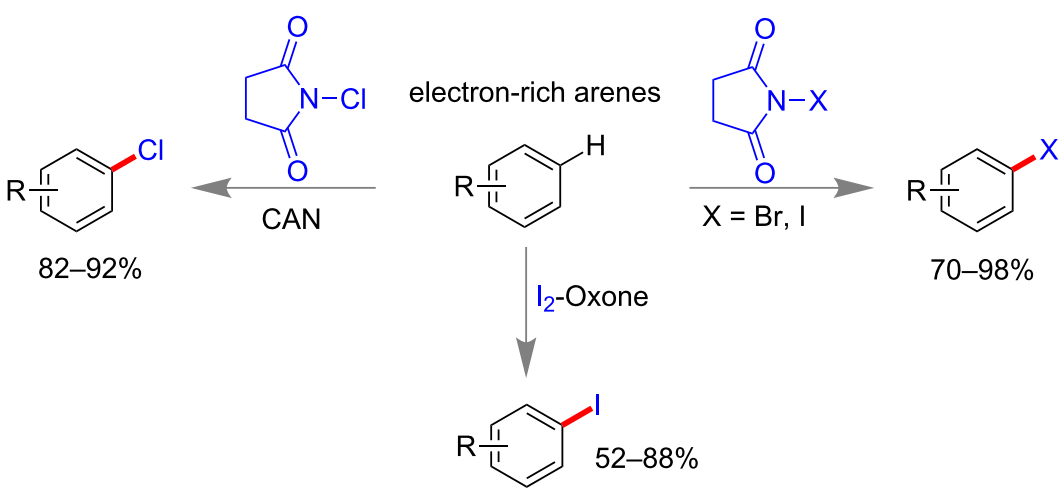

Scheme 25: Mechanochemical halogenation reaction of electron-rich arenes [88,98].

tions of 1,3-dicarbonyl compounds to obtain dihalo derivatives in excellent yield [100].<smiles>[R]c1cccc2ccccc12</smiles>

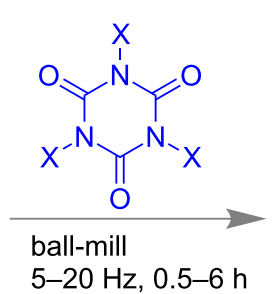

$\mathrm{X}=\mathrm{Br}, \mathrm{Cl}$<smiles>[R]c1ccccc1NO</smiles>

$31-97 \%$
Scheme 26: Mechanochemical aryl halogenation reaction using trihaloisocyanuric acids [100].

In 2016, Browne and co-workers reported selective mechanochemical fluorination of 1,3-dicarbonyl compounds using selectfluor $[101,102]$. They could control the selectivity of the reaction through LAG using ACN $(\approx 10 \% \mathrm{v} / \mathrm{v}$ of total materials) to get predominantly mono-fluorinated product over difluorinated derivatives (Scheme 27). Contrastingly, addition of 1.0 equiv of $\mathrm{Na}_{2} \mathrm{CO}_{3}$ led to switching of the selectivity predominantly towards di-fluorinated product [102].

\section{Multi-component reactions}

Multi-component reactions are one of the most powerful tools for the one pot synthesis of complex molecular structures with various functional groups [103-108]. Starting from the development of the Strecker synthesis of amino acids, many variations have been made till date. In solution these reactions generally proceed via a series of equilibrium processes and finally leading to the product through thermodynamic control $[109,110]$. However, in mechanochemical methods reactions are kinetically controlled [111]. Mechanochemical methods of the Mannich reaction, Paal-Knorr synthesis, Bigineli reaction, Hantzsch reaction, and syntheses of substituted pyran, thiophene, isoquinoline derivatives, etc. are also reported [104,107,112,113]. Isocyanide-based multi-component reactions are also well known [114,115]. Recently, in 2016 Juaristi and co-workers have reported Ugi 4-component reactions (4-CR) by liquid-assisted grinding (LAG) using $\mathrm{MeOH}$. Equimolar amounts of benzaldehyde, chloroacetic acid, tertbutyl isocyanide, and propargylamine in the presence of $2 \mathrm{~mol} \% \mathrm{InCl}_{3}$, under ball-mill yielded the desired Ugi product in $74 \%$ yield (Scheme 28) [116].

Juaristi and co-workers have also reported a mechanochemical Passerine 3-component reaction (3-CR). tert-Butyl isocyanide,<smiles>[R]CC(=O)CCCCCCCC([R])=O</smiles><smiles>[R]C(=O)C(F)C([R])C(=O)O[Na]</smiles>

up to $100 \%$<smiles>[R]C(=O)C(F)(C(=O)NC(=O)O[Na])C(=O)O[Na]</smiles>
selectfluor 

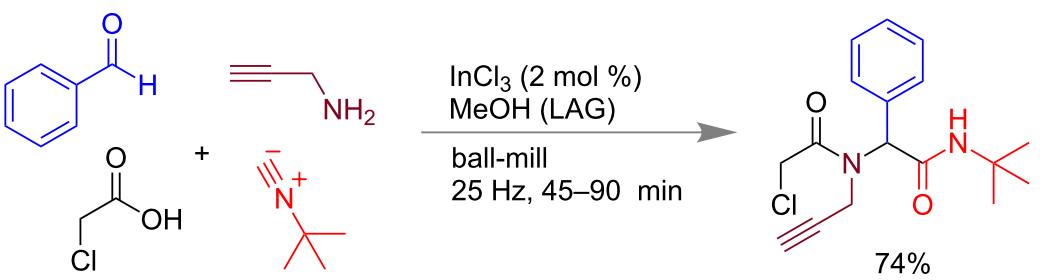

Scheme 28: Mechanochemical Ugi reaction [116].

benzaldehyde and benzoic acid in equimolar proportion under milling conditions for 90 min led to $73 \%$ of Passerine product (Scheme 29). Both electron-donating and -withdrawing substitutions on benzaldehydes or in benzoic acids have worked well under the mechano-chemical conditions [116].

In a multicomponent Strecker reaction the syntheses of $\alpha$-aminonitriles are generally done by condensation of aldehydes, ammonia and hydrogen cyanide $[117,118]$. The aminonitriles are important synthons for the preparation of nitrogencontaining heterocycles and amino acids [119]. In 2016, Bolm and co-workers reported a mechanochemical synthesis of $\alpha$-aminonitriles using benzaldehyde, benzyl amine, $\mathrm{KCN}$ and the milling auxiliary $\mathrm{SiO}_{2}$ to isolate $70-97 \%$ of $\alpha$-aminonitriles as the sole products. Contrastingly, in the solution of acetonitrile imines of benzaldehyde and amines were formed prefer- ably. Different aromatic or heteroaromatic aldehydes including thiophene carboxaldehyde, pyridine carboxaldehyde and cyclohexyl carboxaldehyde as well as various amines like morpholine, aliphatic amines and sulfonamides worked smoothly under these conditions to obtain the desired product in $3 \mathrm{~h}$. They have also extended the methodology for the synthesis of tetrahydroisoquinoline by using $o$-formyl phenethyl bromide with amine and KCN (Scheme 30) [120].

Since the discovery in 1890 , the Hantzsch pyrrole synthesis is well known for the construction of poly substituted pyrroles [121,122]. In 1998, Jung and co-workers reported polymer supported solid phase synthesis of $N$-substituted pyrroles [123]. In 2013, Menendez and co-workers reported a ceric ammonium nitrate (CAN) and silver-nitrate-promoted three-component Hantzsch pyrrole synthesis under ball-milling conditions [121].

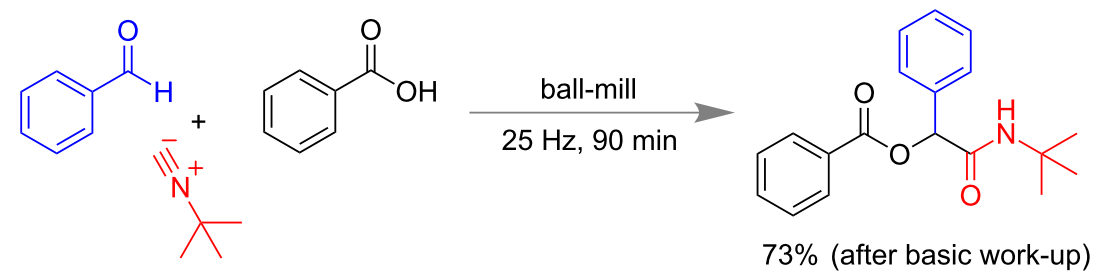

Scheme 29: Mechanochemical Passerine reaction [116].

a) synthesis of $\alpha$-aminonitrile

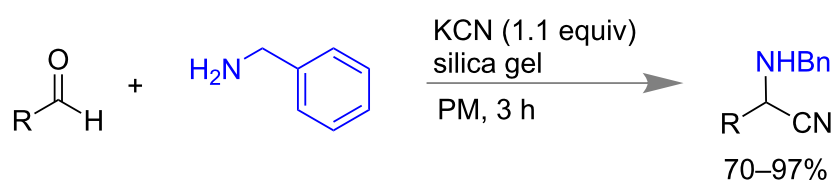

b) application in tetrahydroisoquinolines synthesis
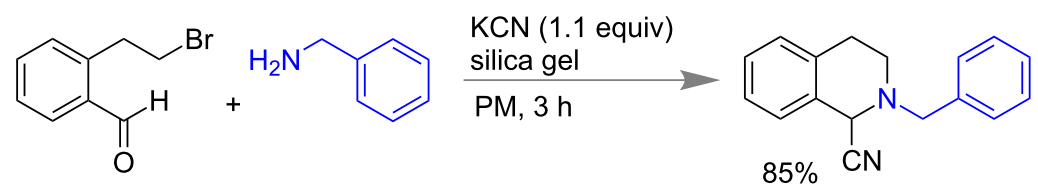
A ketone in presence of $N$-iodosuccinimide (NIS) and $p$-toluenesulfonic acid led to $\alpha$-iodoketone in $1 \mathrm{~h}$. Subsequent addition of the primary amine, $\beta$-dicarbonyl compound, $5 \mathrm{~mol} \%$ $\mathrm{CAN}$ and 1 equiv silver nitrate led to the intermediate $\beta$-enaminone which further reacted with $\alpha$-iodoketone following by a cyclo-condensation which resulted in the substituted pyrroles shown in Scheme 31.

The Biginelli reaction is a well-known 3-component reaction for the synthesis of dihydropyrimidinones [124,125]. During the last few decades many variations are adopted to improve the efficiency of this reaction for practical application towards drug discovery [126-128]. Modifications have been done in substrates by replacing urea with substituted ureas and thio urea, use of various 1,3-dicarbonyl compounds etc. Reactions using ionic liquids as reaction medium, solvent-free synthesis, microwave synthesis, use of different Lewis acids $\mathrm{FeCl}_{3}, \mathrm{NiCl}_{2}$, $\mathrm{BiCl}_{3}, \mathrm{InBr}_{3}$, use of Brønsted acids PTSA, etc. are also reported [129,130]. Recently, Mal and co-workers reported a mechanochemical Biginelli reaction by a subcomponent synthesis approach [131-133] in which the component aldehyde and catalytic amount of acid were generated in situ for the final step of dihydropyrimidinone synthesis. Benzyl alcohols were oxidized by a reagent combination of oxone ( 0.6 equiv), $\mathrm{KBr}$ (10 mol \%) and 2,2,6,6-tetramethylpiperidin-1-yloxy radical (TEMPO, $1 \mathrm{~mol} \%$ ) to give benzaldehydes and $\mathrm{H}^{+}$under solvent-free mechanochemical conditions within $30 \mathrm{~min}$. Further, addition of 1,3-dicarbonyl compounds and urea derivatives within the same milling jar led to the desired products in $78-95 \%$ yield at $3 \mathrm{~h}$ (Scheme 32). Benzaldehydes with electrondonating or -withdrawing groups, heteroaromatic aldehydes, $\mathrm{N}$-methyl urea and thio urea also resulted in good to excellent yield with high regioselectivity. It is interesting to note that the reaction was irreproducible in the solution of ethyl acetate at room temperature even after $24 \mathrm{~h}$ [133].

A mechanochemical asymmetric three component reaction is recently reported by $\mathrm{Su}$ and co-workers in the synthesis of propargyl amines using aldehyde, alkyne and amine under high vibration ball milling (HVBM) condition. Using $10 \mathrm{~mol} \%$ of $\mathrm{Cu}(\mathrm{OTf})_{2}$ as catalyst, $10 \mathrm{~mol} \%$ of Ph-PyBox ligand $\mathbf{C}$ and silica gel as milling auxiliary they could achieve near quantitative synthesis with $>95 \%$ ee at $60 \mathrm{~min}$ (Scheme 33) [134]. However, aldehydes having strong electron-withdrawing or -donat-

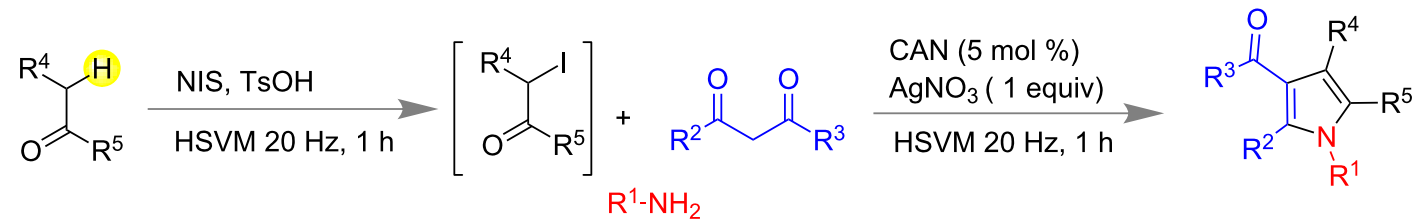

Scheme 31: Mechanochemical Hantzsch pyrrole synthesis [121].

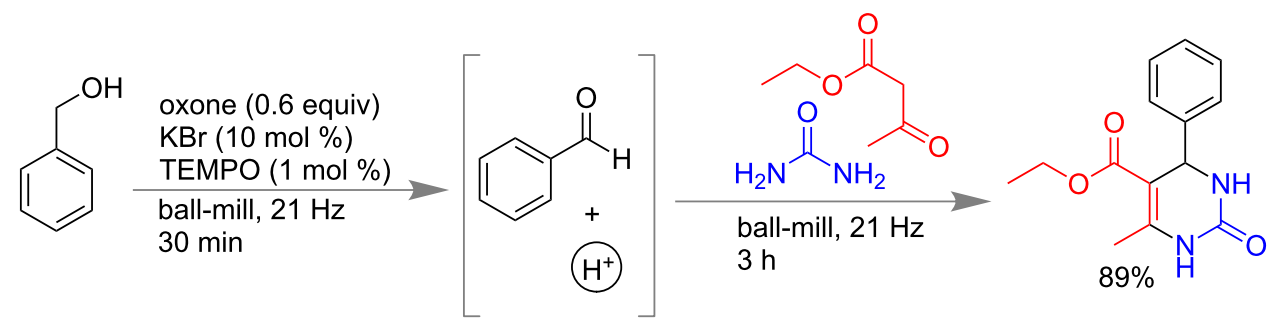

Scheme 32: Mechanochemical Biginelli reaction by subcomponent synthesis approach [133]

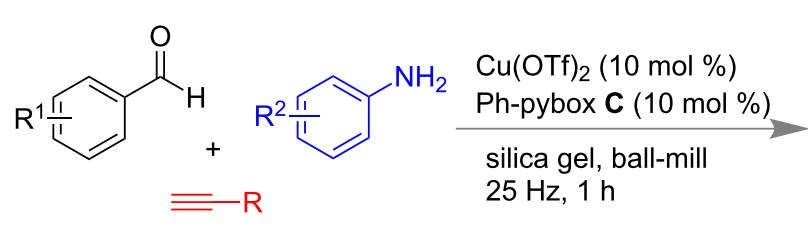<smiles>[R]C#C[C@H](Nc1ccc([R])cc1)c1cc#[R]cc1</smiles><smiles>CC(=O)O[PbH](c1ccccc1)c1cccc(C2=N[C@@H](c3ccccc3)CO2)n1</smiles> 
ing groups yielded the product with lesser enantioselectivity. The silica-supported catalyst could be recovered from the reaction mixture by washing with DCM. They have also observed that an oven-dried catalyst worked effectively to give $99 \%$ of product with $99 \%$ ee up to few cycles.

\section{Heterocycle synthesis}

Multicomponent reactions [135], cyclo-condensations and cascaded transformations are common strategies to make heterocyclic ring [113] systems like pyrroles, pyrans, benzimidazoles, pyrimidines, indoles, etc. [114,136-139]. Further improvements are in demand for the development of synthesis with solvent-less, time efficient, less byproducts, energy saving, easy handling procedures, etc. [112,140,141]. In 2016, Rousseau and co-workers reported a solvent-free mechanochemical Paal-Knorr pyrrole synthesis using a solid bio-sourced acid like citric acid. Using substituted aniline, benzyl or aliphatic amine and 1,4-diketo compounds in presence of $1 \mathrm{~mol} \%$ citric acid under ball-milling afforded the desired $N$-substituted pyrrole with quantitative yield (Scheme 34) [142].

$$
\underbrace{\mathrm{R}^{2}}_{\mathrm{R}-\mathrm{NH}_{2}} \frac{\text { citric acid }(1 \mathrm{~mol} \%)}{\text { ball-mill, } 30 \mathrm{~min}} \underbrace{\mathrm{R}}_{\text {up to } 84 \%}
$$

Scheme 34: Mechanochemical Paal-Knorr pyrrole synthesis [142].

Jang and co-workers reported a mechanochemical synthesis of benzimidazoles [143,144], benzoxazole [145] and benzothiazole derivatives in presence of $\mathrm{ZnO}$ nano particles as catalyst [146]. Using $0.5 \mathrm{~mol} \%$ of $\mathrm{ZnO}$ nano particles which were grown on aromatic imine $\mathbf{D}$ as capping agent, resulted in the best yield within $30 \mathrm{~min}$ at $600 \mathrm{rpm}$. Differently substituted diamines, 2-aminothiophenol and 2-aminophenols reacted with benzaldehyde or aliphatic aldehyde derivatives to give 79-94\% of the desired product (Scheme 35). Major advantage of this method was the regeneration of catalyst by filtration and washing with methanol. Secondly, the method was also applic- able up to $10 \mathrm{~g}$ of 2-aminothiophenol and avoided the use of toxic metals which are common in benzimidazole synthesis $[147,148]$.

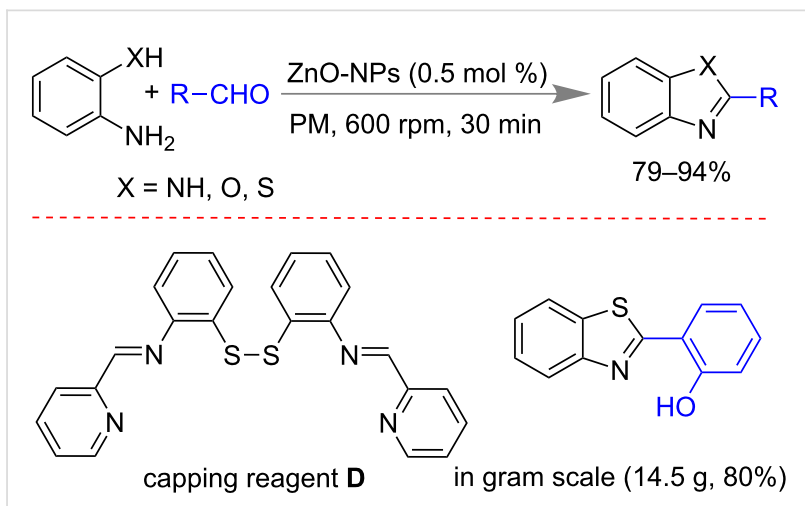

Scheme 35: Mechanochemical synthesis of benzothiazole using $\mathrm{ZnO}$ nano particles [146].

Subsequently, the same group reported the preparation of 1,2disubstituted benzimidazoles via mechanochemical activation using carboxymethylimidazole-based ionic-liquid-coated $\mathrm{ZnO}$ nano particles as catalyst (Scheme 36) [149]. The catalyst worked efficiently till to the fifth cycle after regeneration by filtration of product and washing with methanol. The method was scalable up to using of $8 \mathrm{~g}$ of $o$-phenylene diamine.

1,2,3-Triazoles have important applications in pharmaceutical chemistry [150] and traditionally they are prepared by $1,3-$ dipolar cycloaddition reactions at high temperature, long reaction times and produce low yield with multiple products [151]. In 2013, Ranu and co-workers reported mechanochemical synthesis of triazole moiety (Scheme 37a) using benzyl halides, sodium azide and a terminal alkyne via an alumina-supported copper catalyst. Using $10 \mathrm{~mol} \%$ of $\mathrm{Cu} / \mathrm{Al}_{2} \mathrm{O}_{3}$, differently substituted phenyl acetylenes and aliphatic alkynes led to $70-96 \%$ yield of triazoles [152]. Phenyl boronic acids were also used to synthesize the triazole rings with additional 1 equiv of $\mathrm{K}_{2} \mathrm{CO}_{3}$ which resulted in $>85 \%$ of product (Scheme $37 \mathrm{~b}$ ).

Mack and co-workers reported another mechanochemical variation of "click" reaction $[153,154]$ where they could isolate

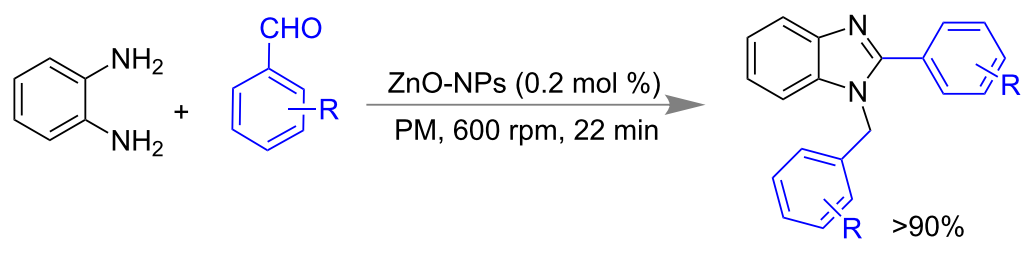


a) cycloaddition using benzyl halide as component

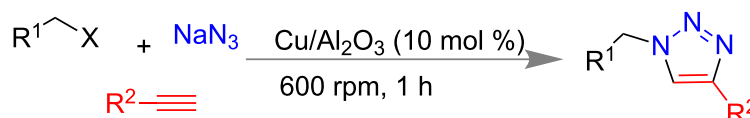

$$
\begin{aligned}
& \text { 70-96\% }
\end{aligned}
$$

b) cycloaddition using boronic acid as component

$$
\underbrace{\mathrm{B}(\mathrm{OH})_{2}}_{\mathrm{Ph}=\mathrm{NaN}_{3}} \frac{\mathrm{Cu}_{\mathrm{K}} \mathrm{Al}_{2} \mathrm{O}_{3}(10 \mathrm{~mol} \%)}{600 \mathrm{rpm}, 1 \mathrm{~h}}
$$

Scheme 37: Mechanochemical click reaction using an alumina-supported Cu-catalyst [152].

$33-90 \%$ of triazole derivatives using copper reaction vial in ball mill for $16 \mathrm{~h}$ (Scheme 38). The same method was easily applicable to the synthesis using alkyl azide in $15 \min$ [155].

$$
\mathrm{R}_{+}^{\mathrm{X}}=\mathrm{NaN}_{3} \frac{\text { copper vial, balls }}{16 \mathrm{~h}}
$$<smiles>[R]c1cn(Cc2c[R7]ccc2)nn1</smiles>

$33-90 \%$

Scheme 38: Mechanochemical click reaction using copper vial [155]

Among various synthetic routes of indoles synthesis, Larock method [156] possibly be the important one which utilizes 2-alkynylaniline as intermediate towards intra-molecular cyclization. Stolle and co-workers also demonstrated mechanochemical synthesis of indoles using stoichiometric amounts of $\mathrm{ZnBr}_{2}$ and $\mathrm{NaCl}$ as milling auxiliary starting from 2-alkynylaniline derivatives (Scheme 39) [157]. They have correlated the milling frequency and time of reaction to the product yields and selectivity. For example, a) at higher frequency $\left(800 \mathrm{~min}^{-1}\right)$ for 45 min lower yield with less selectivity was observed and b) using lower frequency, $200 \mathrm{~min}^{-1}$ for $8 \mathrm{~h}$ led to $82 \%$ of yield with high selectivity.

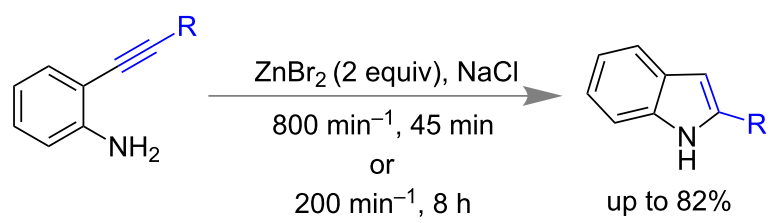

Scheme 39: Mechanochemical indole synthesis [157].

In the traditional method of pyran synthesis the use of transition metal catalyst, corrosive acid, longer reaction time, hazardous organic solvent, and tedious isolation procedure are implemented. Dekamin and co-workers have demonstrated the synthesis of pyrans using potassium phthalimide (POPI) as a catalyst under ball-milling which is found to be advantageous over solution phase synthesis [158]. Malonitrile, benzaldehydes and electron-rich phenols in presence of $5 \mathrm{~mol} \%$ of POPI, afforded near quantitative yield of chromene derivatives within 20 min (Scheme 40). Similarly, various benzaldehydes with electron-withdrawing groups at the $o / p$-position accelerated the reaction and electron-donating groups slowed that down. Hetero aromatic aldehydes also worked efficiently to give the products in $96-98 \%$ yield [158].

Acenes and hetero-acenes have important applications in material development such as semiconductors, photovoltaic cells, field effect transistors, organic light emitting diodes, etc. [159165]. Moreover, the literature known methods adopted mainly harsh reaction condition and they are generally found to be low yielding [166-168]. Recently, Mal and co-workers reported mechanochemical synthesis of hetero-acenes from 1,2-dicarbonyl compounds and 1,2-diaminoarenes using $10 \mathrm{~mol} \% p$-toluenesulfonic acid as catalyst. Using this process they could isolate $72-96 \%$ of pyrazaacene, phenazine, bis(phenazine), bis(quinoxaine) derivatives (Scheme 41). Major advantages of this mechanomilling methods were time efficient $(2-4 \mathrm{~h})$, simple purification procedure (washing with polar solvent), high yielding, room temperature conditions, etc. Previously reported solvent-based synthesis required reflux for 3 days to get $30-40 \%$ yield [169].

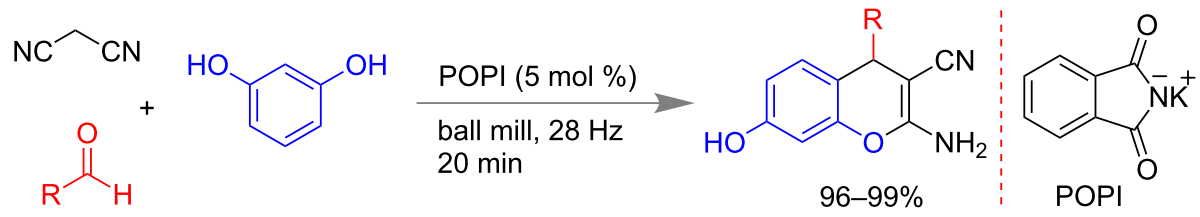




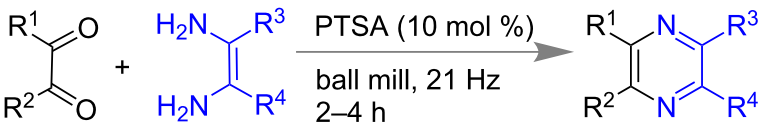

$$
\begin{aligned}
& \text { 72-96\% }
\end{aligned}
$$

Scheme 41: Mechanochemical synthesis of azacenes [169]

\section{Miscellaneous bond formation reaction} Carbon-phosphorus bond synthesis

Recently, Wang and co-workers reported the first carbon-phosphorous (C-P) bond synthesis under mechanochemical conditions. Phosphonylation of benzothiazole and thiazole derivatives were done with organophosphorus compounds using 3 equiv of $\mathrm{Mn}(\mathrm{OAc})_{3} \cdot 2 \mathrm{H}_{2} \mathrm{O}$ in a mixer mill for $1.5 \mathrm{~h}$. Benzothiazole or thiazole rings having electron-donating or -withdrawing groups worked efficiently under this protocol. Different organophosphorus compounds including phosphine oxides, phosphinate ester, and phosphonate diester underwent C-P bond formation to give $22-94 \%$ of yield (Scheme 42 ). This method was also found to be applicable in gram scale synthesis with excellent yield. Mechanistically they have shown that the reaction followed a radical pathway [170].

\section{C-Chalcogen bond formation}

Ranu and co-workers reported carbon-chalcogen (C-S, C-Se, $\mathrm{C}-\mathrm{Te}$ ) bond formation from aryldiazonium tetrafluoroborate ( 1 equiv), diaryl chalocogenide ( 0.5 equiv) in a stainless steel jar at $600 \mathrm{rpm}$ for $15 \mathrm{~min}$. They have used $\mathrm{KOH}$ as base, neutral alumina as milling auxiliary. Both electron-donating and -withdrawing diazonium salts worked efficiently to give $70-90 \%$ of the products (Scheme 43) [171]. This solvent-free mechanomilling strategy reported to be superior to any solution phase synthesis because it avoids transition metals, could be performed in shorter reaction time and uses stable dichalcogenides rather than toxic thiols and selenols.

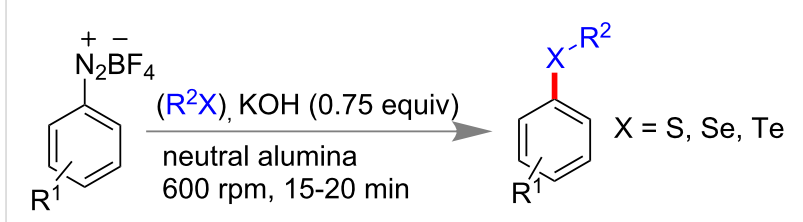

Scheme 43: Mechanochemical C-chalcogen bond formation [171].

\section{Organometallic synthesis and catalytic application}

\section{Mechano-synthesis of organometallic compounds}

The last decade has witnessed a rapid growth of mechanochemistry in organic synthesis as well as in inorganic coordination chemistry [172]. However, the mechanochemical organometallic synthesis is still in its infancy due to certain difficulties under solvent-free synthesis. Recently the solid state syntheses of organometallic compounds have become popular. In their pioneering work Coville and co-workers presented solvent-free organometallic transformations (e.g., migratory insertion and ligand substitution reactions) at elevated temperature (Scheme 44) which have close resemblance to mechanochemistry [173].

$$
\text { solvent free (melt) }
$$

Scheme 44: Solvent-free synthesis of an organometallic complex.

The examples of mechanochemical organometallic complex synthesis are relatively small, but experienced significant growth in recent times. In the early 1990s, the first examples of mechanochemical organometallic reactions were discovered, included the synthesis of various indenyl, cyclopentadienyl and metallocarborane complexes [174]. In Scheme 45, few exam-

a) carbon-phosphorous bond formation

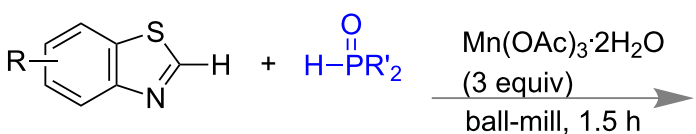

b) application to gram scale synthesis<smiles>[R][R](=O)c1nc2cc[R]cc2s1</smiles>

$22-94 \%$<smiles>O=[PH](=O)(O)c1nc2ccccc2s1</smiles> 
a) halogenation of organometallic $\operatorname{Re}(\mathrm{I})$ complex
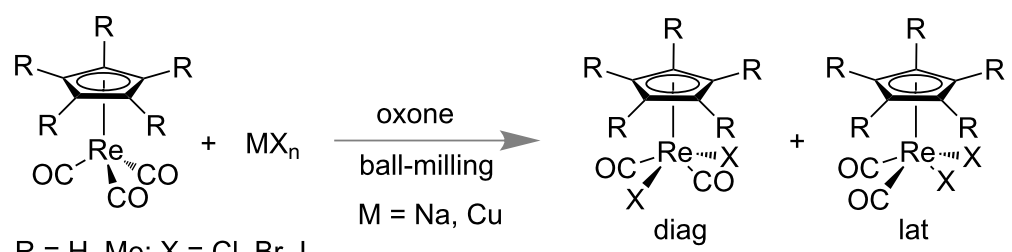

$\mathrm{R}=\mathrm{H}, \mathrm{Me} ; \mathrm{X}=\mathrm{Cl}, \mathrm{Br}$, I

b) multistep and multicomponent organometallic synthesis

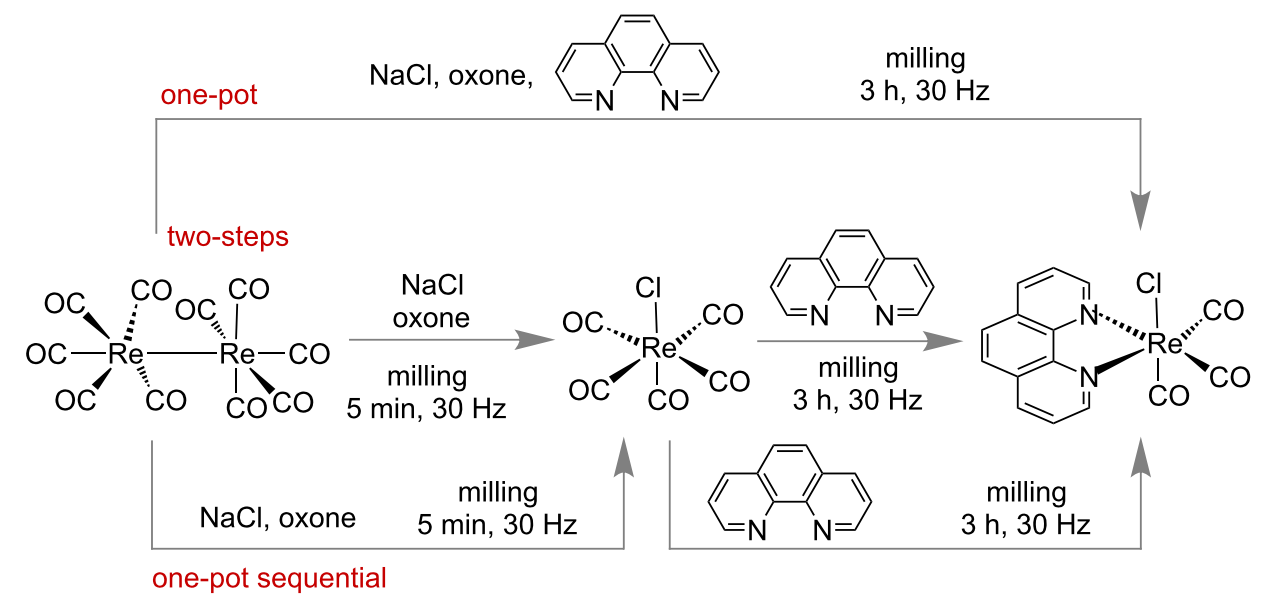

c) mechanosynthesis of $\mathrm{N}$-heterocyclic carbene-gold complexes
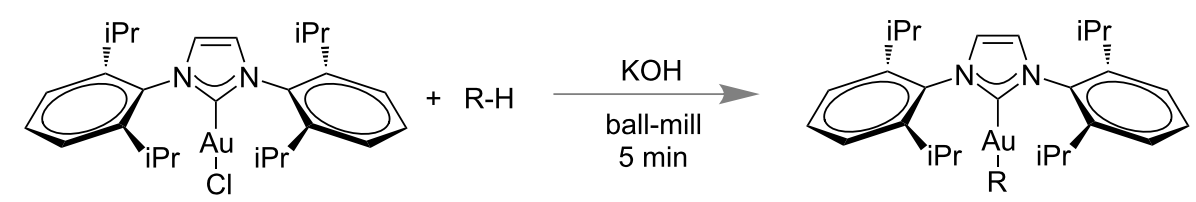

$\mathrm{R}=$ aromatic, aliphatic (needed to be acidic enough)

Scheme 45: Selective examples of mechano-synthesis of organometallic complexes. a) Halogenation reaction of Re-complexes [175]. b) Multistep and multicomponent synthesis of Re-complexes [176]. c) Mechano-synthesis of NHC-Au complex [177].

ples of mechanosynthesis of organometallic complexes are shown.

Ćurić and co-workers reported the first mechanochemical activation of a $\mathrm{C}-\mathrm{H}$ bond of unsymmetrical azobenzene with $\mathrm{Pd}(\mathrm{OAc})_{2}$ [178]. The cyclopalladation process was highly regioselective and the rate of palladation was also faster than traditional solution phase processes. 4'-( $N, N$-dimethylamino)-4nitroazobenzene with an equimolar amount of $\mathrm{Pd}(\mathrm{OAc})_{2}$ and $25 \mu \mathrm{L}$ of glacial acetic acid (for $\mathrm{LAG}$ ) resulted in regioselective $\mathrm{C}-\mathrm{H}$ activation to give cyclopalladated complex $\mathbf{E}$ in $4.5 \mathrm{~h}$ where two Pd- and two azobenzene groups were involved. Treating this complex with another 1 equiv of $\mathrm{Pd}(\mathrm{OAc})_{2}$ resulted in a second $\mathrm{C}-\mathrm{H}$ activation to give dicyclopalladated complex $\mathbf{F}$ in $7.5 \mathrm{~h}$ (Scheme 46). It is notable that the monocy- clopalladated complexation generally takes 3 days in solution and dicyclopalladated complex in solution was never been identified [178].

Recently Aleksanyan and co-workers reported the first gramscale synthesis of a Pd ${ }^{\mathrm{II}}$ organometallic pincer complex under mechanomilling via $\mathrm{C}-\mathrm{H}$ bond activation. After successful isolation of the $\mathrm{Pd}^{\mathrm{II}}$ pincer complex by grinding of bis(thiocarbamate) and $\mathrm{PdCl}_{2}(\mathrm{NCPh})_{2}$ they could scale up the reaction up to $1.76 \mathrm{mmol}$. Using a stainless steel jar they could isolate $95 \%$ of the pure pincer complex within 2 min (Scheme 47) [179].

Hanusa and co-workers developed a base-free mechanochemical synthesis of a tris(allyl)aluminum complex. Importantly, unsolvated tris(allyl)aluminum was never been isolated from 


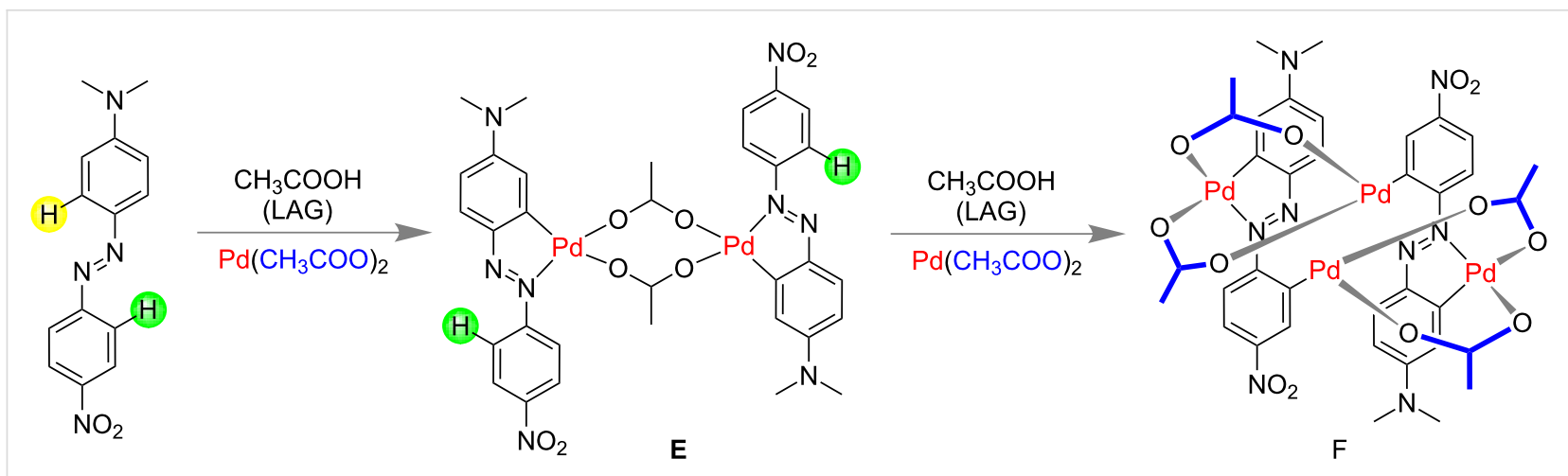

Scheme 46: Mechanochemical activation of $\mathrm{C}-\mathrm{H}$ bond of unsymmetrical azobenzene [178].<smiles>CNC(=S)Oc1cccc(OC(N)=S)c1P(=S)(Cl)Oc1ccccc1OC(C)=O</smiles>

Scheme 47: Mechanochemical synthesis of organometallic pincer complex [179].

solution, but mechanochemically found to be a high yielding reaction when bulky 1,3-bis(trimethylsilyl)allyl anion (Scheme 48) was reacted with aluminum iodide [180].

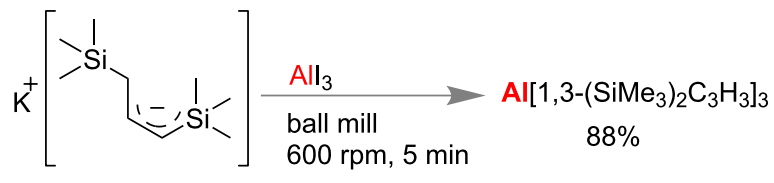

Scheme 48: Mechanochemical synthesis of tris(allyl)aluminum complex [180].

\section{Catalytic application}

The success of the mechanochemical synthesis over traditional solvent-based synthesis in different areas has been recognized over the decades. Importantly catalytic application of these mechano-synthesized complexes are also explored. Friščić and co-workers recently reported an efficient mechanochemical approach towards Ru-based Hoveyda-Grubbs catalyzed olefin metathesis, cross-metathesis and ring-closing metathesis reactions (Scheme 49) [181]. Advantageously this methodology was applicable for both solid and liquid olefins.

\section{Mechanochemical C-H functionalization}

Transition-metal-catalyzed activation and functionalization of inert $\mathrm{C}-\mathrm{H}$ bonds of organic molecules provides a broad avenue in the synthesis of wide range of compounds. In 2015, Bolm and co-workers have successfully demonstrated rhodium(III)catalyzed $\mathrm{C}-\mathrm{H}$ bond functionalization under mechanochemical conditions [182]. Advantageously, the developed method adopted mild reaction conditions, i.e., in solvent-free medium and at room temperature. It required a minimum amount of toxic metal salt of $\mathrm{Rh}, \mathrm{Cu}(\mathrm{OAc})_{2}$ as a redox modulator and dioxygen as a terminal oxidant (Scheme 50). This efficient technique was turned out to be a greener alternative to the common and mechanistically similar solution based method.

They have also extended mechanochemical $\mathrm{C}-\mathrm{H}$ functionalization methodology by varying the metal catalyst from rhodium to iridium. In 2016, using an $\operatorname{Ir}(\mathrm{III})$ catalyst an unprecedented ortho-selective $\mathrm{Csp}^{2}-\mathrm{H}$ bond amidation of benzamides with sulfonyl azides as the amide source was done under solvent-free ball mill conditions (Scheme 51) [183]. They could also isolate cyclic iridium complex $\mathbf{H}$ in ball-milling conditions.

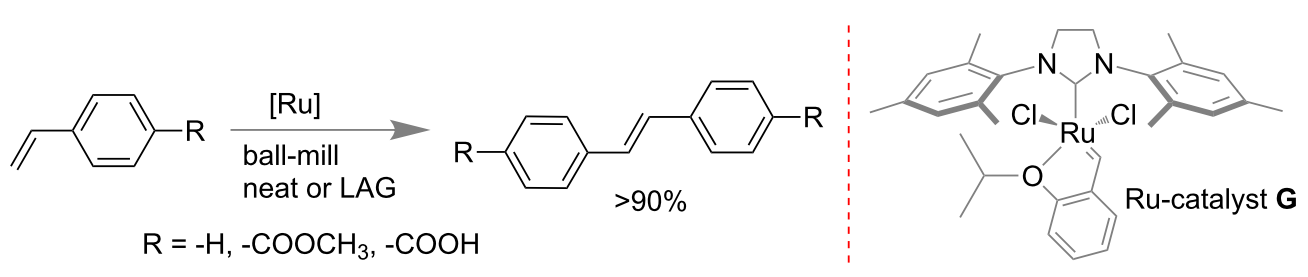




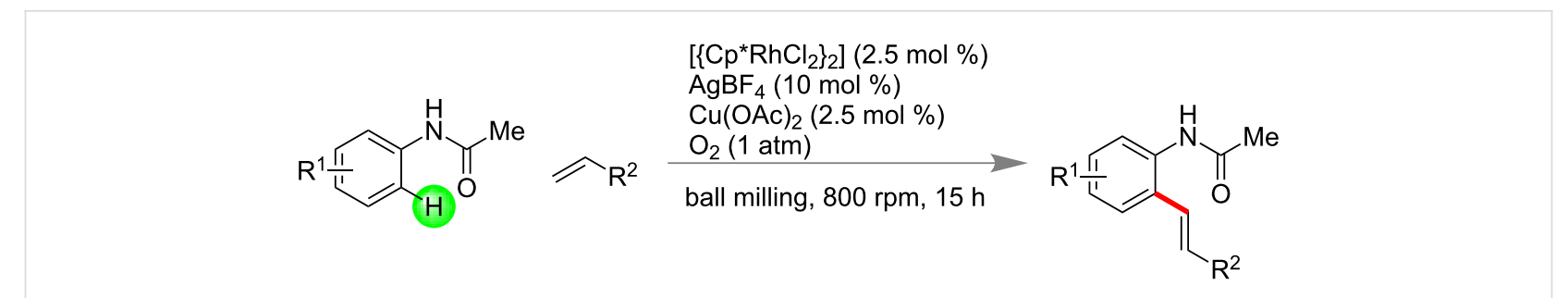

Scheme 50: Rhodium(III)-catalyzed C-H bond functionalization under mechanochemical conditions [182].<smiles>[R1]NC(=O)c1cc[R1]([H])cc1</smiles>

$\left[\left\{\mathrm{Cp}^{*} \mathrm{IrCl}_{2}\right\}_{2}\right](2.5 \mathrm{~mol} \%)$

$\mathrm{AgBF}_{4}(10 \mathrm{~mol} \%)$

$\operatorname{AgOAc}(10 \mathrm{~mol} \%)$

ball-mill, $30 \mathrm{~Hz}$ $99 \mathrm{~min}$
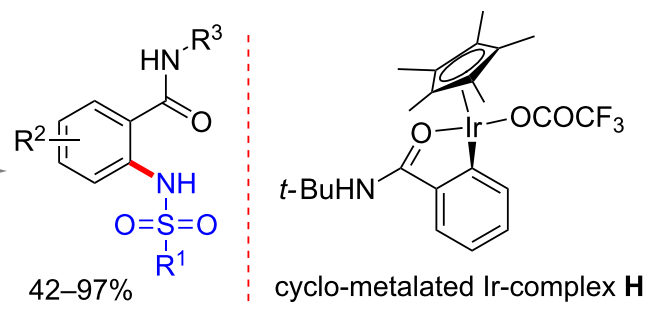

Scheme 51: Mechanochemical Csp²-H bond amidation using Ir(III) catalyst [183].

In 2015, the Bolm group reported the synthesis of $\left[\mathrm{Cp} * \mathrm{RhCl}_{2}\right]_{2}$ under LAG from rhodium(III) chloride hydrate and pentamethylcyclopentadiene $\left(\mathrm{Cp}^{*} \mathrm{H}\right)$ at lesser reaction time than solution-based protocols. Subsequently, they utilized the $\left[\mathrm{Cp} * \mathrm{RhCl}_{2}\right]_{2}$ for the solvent-free mechanochemical $\mathrm{C}-\mathrm{H}$ bond functionalization of 2-phenylpyridine (Scheme 52). With 2.2 equiv of $\mathrm{NXS}(\mathrm{X}=\mathrm{Br}, \mathrm{I})$ and $5 \mathrm{~mol} \%$ of $\left[\mathrm{Cp}^{*} \mathrm{RhCl}_{2}\right]_{2}$ catalyst in a mixer mill, $74 \%$ and $84 \%$ of dibromo- and diiodo derivatives of 2-phenylpyridine, respectively, were isolated within $3 \mathrm{~h}[184]$.
$\mathrm{Xu}$ and co-workers developed a palladium-catalyzed site selective mechanochemical dehydrogenative $\mathrm{C}-\mathrm{H} / \mathrm{C}-\mathrm{H}$ arylation between oxime and arene moiety for the construction of $\mathrm{C}_{\mathrm{sp} 2}-\mathrm{C}_{\mathrm{sp} 2}$ bond with high para-selectivity of arene component via LAG. Using $10 \mathrm{~mol} \%$ of $\mathrm{Pd}(\mathrm{OAc})_{2}, 2.0$ equiv of $\mathrm{Na}_{2} \mathrm{~S}_{2} \mathrm{O}_{8}$ and 1.0 equiv $\mathrm{TfOH}$ the biaryls were synthesized in good to excellent yield within $1 \mathrm{~h}$. Dimethyl formamide (DMF) acted as ligand during the activation process (Scheme 53). The protocol was also equally applicable to electron deficient oximes and electron rich anilides [185].

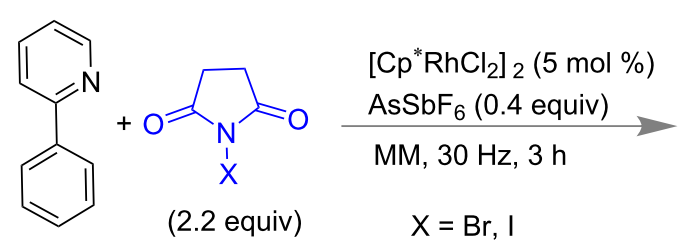

(2.2 equiv)
$\mathrm{X}=\mathrm{Br}, \mathrm{I}$

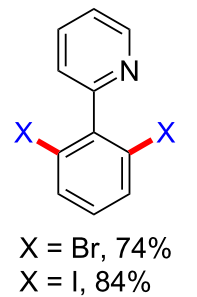

$\mathrm{X}=1,84 \%$

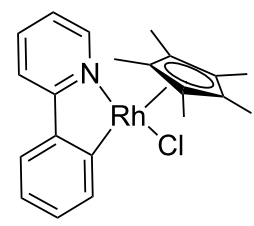

cyclic rhodium intermediate I

Scheme 52: Mechanochemical Rh-catalyzed $C_{s p 2}-X$ bond formation [184].<smiles>[R]c1ccc([18F])cc1</smiles>

$\mathrm{Pd}(\mathrm{OAc})_{2}(10 \mathrm{~mol} \%)$

$\mathrm{Na}_{2} \mathrm{~S}_{2} \mathrm{O}_{8}$ (2 equiv)

DMF (2 equiv)

$\mathrm{TfOH}$ (1 equiv)

$\mathrm{PM}, 1 \mathrm{~h}$<smiles>[R]c1ccc(-c2ccc[R1]c2/C(C)=N/OC)cc1</smiles>

up to $85 \%$ 
Bolm and co-workers reported a Rh-catalyzed amidation of $\mathrm{Csp}^{2}-\mathrm{H}$ bonds using dioxazolone as the amide source under ball milling conditions (Scheme 54). Using $5 \mathrm{~mol} \%$ of Rh catalyst,

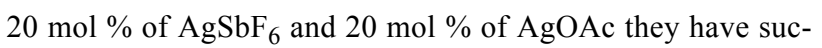
cessfully achieved up to $99 \%$ of ortho-amidation product with diversely substituted arene moiety [186].

Recently Bolm and co-workers developed a mechanochemical synthesis of an indole moiety via a Rh-catalyzed $\mathrm{C}-\mathrm{H}$ functionalization strategy under planetary ball mill [187]. Using acetanilide and diphenylacetylene as the alkyne component in presence of $5 \mathrm{~mol} \% \mathrm{Rh}$ catalyst and $2.5 \mathrm{~mol} \% \mathrm{Cu}(\mathrm{OAc})_{2}$ and $1 \mathrm{~atm} \mathrm{O}_{2}$ as terminal oxidant they could isolate up to $77 \%$ of differently substituted indole derivatives (Scheme 55).

\section{Advantages and limitations}

Over a couple of decades the area of mechanochemistry considered to be one of the best solvent-free synthetic methods. This area has become significantly interesting to chemists due to its benefits over conventional solution-based protocols. Importantly in mechanochemistry, avoiding traditional work-up might be considered as one of the major beneficial aspects. This benefit also leading to a significant development to green processes, turned out to be economical, time-efficient and environmentally benign. Easy purification procedures, towards quantitative conversion and minimum byproducts are additionally considered to be major significance to this method. Tullberg et al. investigated the Mizoroki-Heck reaction between iodobenzene and the methyl ester of $N$-Boc-protected aminoacylate under different conditions of energy (Scheme 56) and showed that efficiency under mechanomilling is far better over other methods [58].

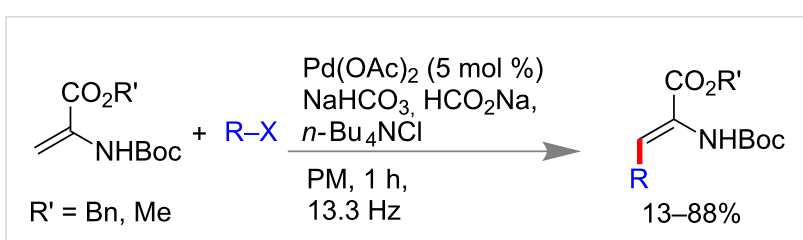

Scheme 56: Mizoroki-Heck reaction of aminoacrylates with aryl halide in a ball-mill [58].

Mal and co-workers have addressed the efficiency of 2-iodoxybenzoic acid (IBX) under mechanomilling conditions (Scheme 57) [8]. Generally the major drawback of IBX is its insolubility in common organic solvents except DMSO and also its explosive nature at higher temperature [188]. They could overcome these limitations by using IBX under solvent-free mechanomilling conditions. They have demonstrated various oxidation reactions, synthesis of benzimidazoles, deprotection of dithianes, etc. The byproduct iodosobenzoic acid (IBA) was recycled over 15 cycles with the help of the oxidant oxone. The economic benefits of IBX under ball milling was also discussed by comparing the literature-known DMSO mediated procedure [8].

The bis(benzotriazolyl)methanethione-assisted thiocarbamoylation of anilines proceed through the formation of unisolable reactive intermediate, aryl $N$-thiocarbamoylbenzotriazole, which rapidly decomposes to the corresponding isothiocyanate in organic solvent [189]. The Štrukil and Friščić group successfully demonstrated the formation of aryl- $N$-thiocarbamoylbenzotriazole under the LAG (liquid-assisted grinding) synthesis (Scheme 58) [190]. Initially, in situ monitoring of mechanochemical thiocarbamoylation suggests the formation of
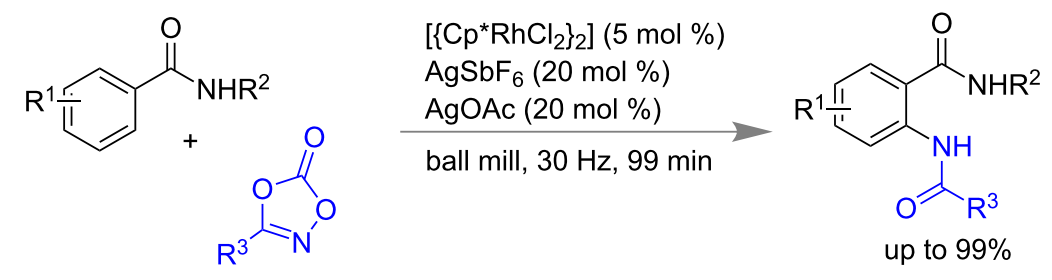

Scheme 54: Mechanochemical $\mathrm{Csp}^{2}-\mathrm{H}$ bond amidation using $\mathrm{Rh}$ catalyst.

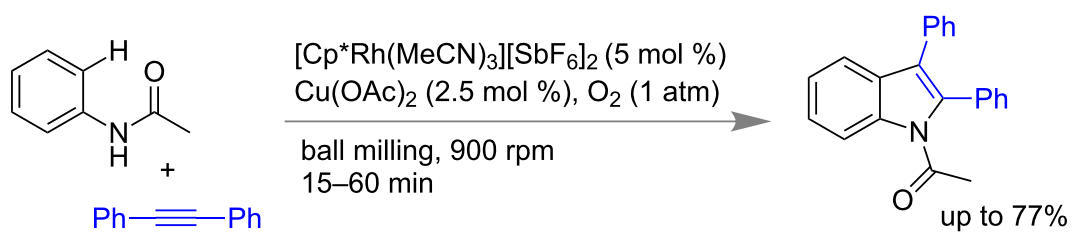

Scheme 55: Mechanochemical synthesis of indoles using Rh catalyst [187]. 


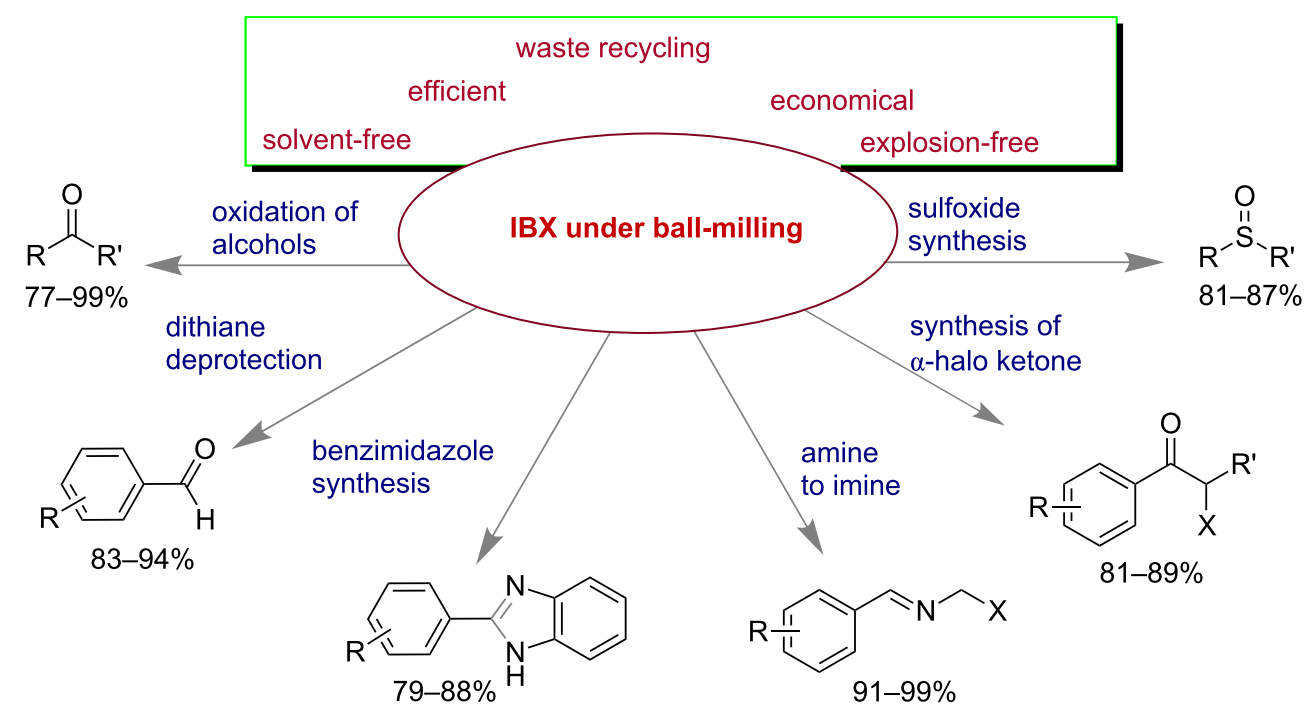

Scheme 57: IBX under mechanomilling conditions [8]

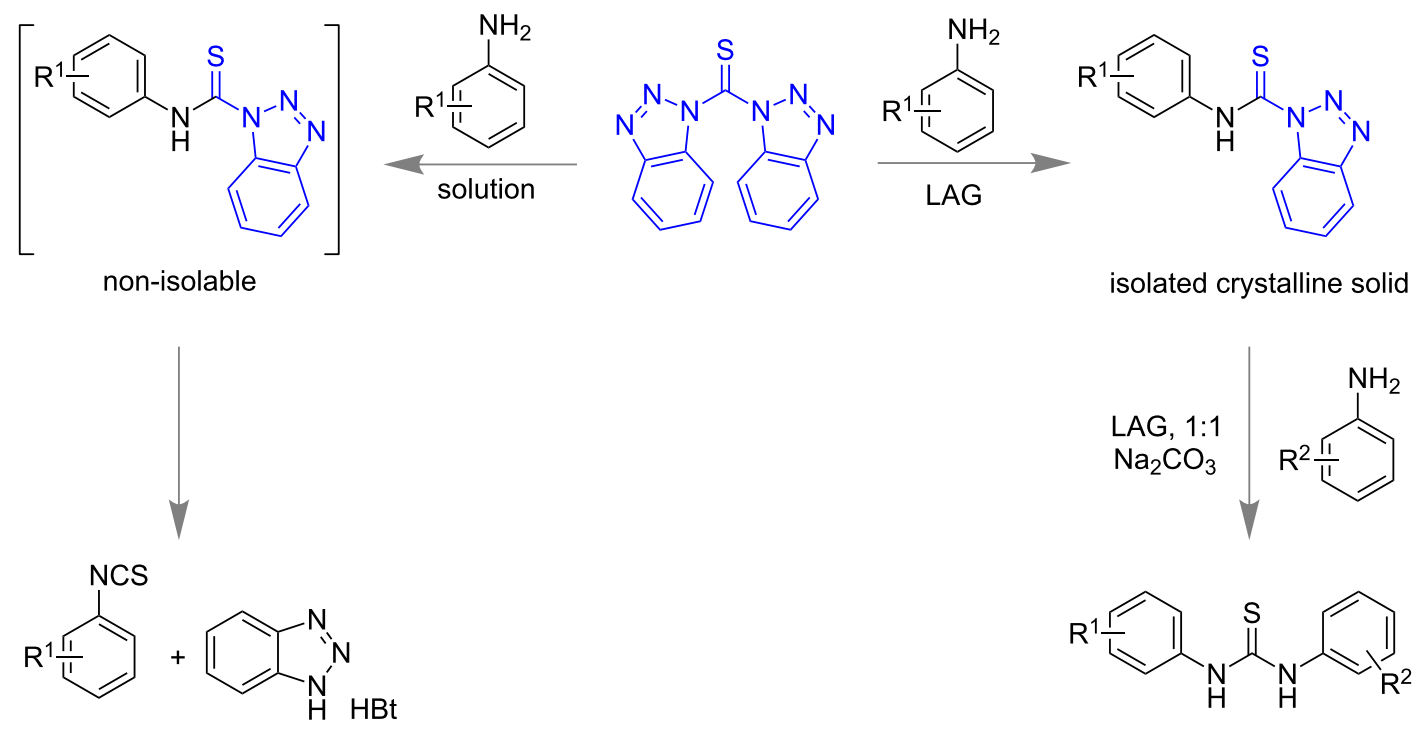

Scheme 58: Thiocarbamoylation of anilines; trapping of reactive aryl- $N$-thiocarbamoylbenzotriazole intermediate in mechanochemical synthesis while not isolable in solution-based synthesis [190].

reactive intermediate which gradually disappears with the formation of thiocarbamoylated product. Furthermore isolation and spectroscopic characterization of aryl- $N$-thiocarbamoylbenzotriazole intermediate clearly established the advantage of mechanochemistry over traditional solution-based synthesis and unwraps a new avenue for the mechanistic study as a promising technique.

Recently, the field of $\mathrm{C}-\mathrm{H}$ activation has gained huge attention of chemists. It allows selective functionalization of $\mathrm{C}-\mathrm{H}$ bonds to $\mathrm{C}$-hetero atoms as discussed herein. Moreover, the major drawbacks are involvement of harsh reaction conditions like high temperature, longer reaction time, and huge amount of toxic organic solvents and handling of sensitive metal catalyst. But fortunately, mechanochemistry has overcome all these limitations and proved to be advantageous since it uses minimum amount of solvents, shorter reaction time, and easy handling of reagents and room temperature conditions. Despite the advantages of ball milling in chemical synthesis still there are some limitations to be noted. Mechanochemical methods are general- 
ly uncontrollable to temperature controlled reactions, time controlled reactions, in handling low boiling liquids, moisture sensitive systems, heterogeneous reactions, pressure controlled reactions, etc. The mechanochemistry is focused on making the known solution-based synthetic procedures more environmentally friendly by avoiding the solvent which is also one of the major drawbacks. So development of innovative bond formation reactions under mechanomilling should be highly appreciated that are inaccessible from solution phase chemistry.

\section{Conclusion}

Significant progress has been made under the area of mechanochemistry during the last few decades owing to their improvement of environmentally sustainable and more selective processes. The major focus of this review is to cover the application of mechanochemistry in the synthesis of small organic molecules including heterocycles. In addition, the mechanosynthesis of organometallics as well as their selective applications in catalysis are also discussed. The understanding of the mechanism of mechanochemical reactions is still unclear and requires significant advancement in this research area. Improvement in new synthetic methodologies under mechanomilling conditions with better results are always demanding, rather than "greening" the solution phase synthesis.

\section{Acknowledgements}

We thank DST (New Delhi, India) for support. T.K.A. and A.B. thank UGC (India) and CSIR (India), respectively, for fellowship.

\section{References}

1. Kulla, H.; Wilke, M.; Fischer, F.; Röllig, M.; Maierhofer, C.; Emmerling, F. Chem. Commun. 2017, 53, 1664-1667. doi:10.1039/c6cc08950j

2. Ravelli, D.; Dondi, D.; Fagnoni, M.; Albini, A. Chem. Soc. Rev. 2009, 38, 1999-2011. doi:10.1039/b714786b

3. Walsh, P. J.; Li, H.; de Parrodi, C. A. Chem. Rev. 2007, 107, 2503-2545. doi:10.1021/cr0509556

4. Constable, D. J. C.; Dunn, P. J.; Hayler, J. D.; Humphrey, G. R.; Leazer, J. L., Jr.; Linderman, R. J.; Lorenz, K.; Manley, J.; Pearlman, B. A.; Wells, A.; Zaks, A.; Zhang, T. Y. Green Chem. 2007, 9, 411-420. doi:10.1039/B703488C

5. DeVierno Kreuder, A.; House-Knight, T.; Whitford, J.; Ponnusamy, E.; Miller, P.; Jesse, N.; Rodenborn, R.; Sayag, S.; Gebel, M.; Aped, I.; Sharfstein, I.; Manaster, E.; Ergaz, I.; Harris, A.; Nelowet Grice, L. ACS Sustainable Chem. Eng. 2017, 5, 2927-2935. doi:10.1021/acssuschemeng.6b02399

6. Tobiszewski, M.; Mechlińska, A.; Namieśnik, J. Chem. Soc. Rev. 2010, 39, 2869-2878. doi:10.1039/b926439f

7. O'Brien, M.; Denton, R.; Ley, S. V. Synthesis 2011, 1157-1192. doi:10.1055/s-0030-1259979

8. Achar, T. K.; Maiti, S.; Mal, P. RSC Adv. 2014, 4, 12834-12839. doi:10.1039/C4RA00415A
9. Margetić, D.; Štrukil, V. Mechanochemical Organic Synthesis; Elsevier: Boston, 2016; pp 1-54. doi:10.1016/B978-0-12-802184-2.00001-7

10. Bhutia, Z. T.; Prasannakumar, G.; Das, A.; Biswas, M.; Chatterjee, A.; Banerjee, M. ChemistrySelect 2017, 2, 1183-1187. doi:10.1002/slct.201601672

11. Margetić, D.; Štrukil, V. Mechanochemical Organic Synthesis; Elsevier: Boston, 2016; pp 351-360. doi:10.1016/B978-0-12-802184-2.00009-1

12. Baig, R. B. N.; Varma, R. S. Chem. Soc. Rev. 2012, 41, 1559-1584. doi:10.1039/c1cs15204a

13. Do, J.-L.; Friščić, T. ACS Cent. Sci. 2017, 3, 13-19. doi:10.1021/acscentsci.6b00277

14. Stauch, T.; Dreuw, A. Chem. Rev. 2016, 116, 14137-14180. doi:10.1021/acs.chemrev.6b00458

15. IUPAC. Compendium of Chemical Terminology, 2nd ed. (the "Gold Book"). Compiled by A. D. McNaught and A. Wilkinson. Blackwell Scientific Publications, Oxford (1997).

16. Kajdas, C. General Approach to Mechanochemistry and Its Relation to Tribochemistry. Tribology in Engineering; InTech, 2013; pp 209-240. doi: $10.5772 / 50507$

17. Cintas, P.; Tagliapietra, S.; Caporaso, M.; Tabasso, S.; Cravotto, G. Ultrason. Sonochem. 2015, 25, 8-16. doi:10.1016/j.ultsonch.2014.12.004

18. Baláž, P.; Achimovičová, M.; Baláž, M.; Billik, P.; Cherkezova-Zheleva, Z.; Criado, J. M.; Delogu, F.; Dutková, E.; Gaffet, E.; Gotor, F. J.; Kumar, R.; Mitov, I.; Rojac, T.; Senna, M.; Streletskii, A.; Wieczorek-Ciurowa, K. Chem. Soc. Rev. 2013, 42, 7571-7637. doi:10.1039/C3CS35468G

19. Zhang, H.; Lin, Y.; Xu, Y.; Weng, W. Top. Curr. Chem. 2015, 369, 135-207.doi:10.1007/128_2014_617

20. Cintas, P.; Cravotto, G.; Barge, A.; Martina, K. Top. Curr. Chem. 2015, 369, 239-284. doi:10.1007/128_2014_623

21. Smalø, H. S.; Rybkin, V. V.; Klopper, W.; Helgaker, T.; Uggerud, E. J. Phys. Chem. A 2014, 118, 7683-7694. doi:10.1021/jp504959z

22. Toda, F. Acc. Chem. Res. 1995, 28, 480-486. doi:10.1021/ar00060a003

23. Tanaka, K.; Toda, F. Chem. Rev. 2000, 100, 1025-1074. doi:10.1021/cr940089p

24. Kaupp, G. Kirk-Othmer Encyclopedia of Chemical Technology; John Wiley \& Sons, Inc., 2012. doi:10.1002/0471238961.solvkaup.a01

25. Friščić, T. Chem. Soc. Rev. 2012, 41, 3493-3510. doi:10.1039/c2cs15332g

26. Margetić, D.; Štrukil, V. Mechanochemical Organic Synthesis; Elsevier: Boston, 2016; pp 343-350. doi:10.1016/B978-0-12-802184-2.00008-X

27. Wang, G.-W. Chem. Soc. Rev. 2013, 42, 7668-7700 doi:10.1039/C3CS35526H

28. Hernández, J. G.; Friščić, T. Tetrahedron Lett. 2015, 56, 4253-4265. doi:10.1016/j.tetlet.2015.03.135

29. James, S. L.; Adams, C. J.; Bolm, C.; Braga, D.; Collier, P.; Friščić, T.; Grepioni, F.; Harris, K. D. M.; Hyett, G.; Jones, W.; Krebs, A.; Mack, J.; Maini, L.; Orpen, A. G.; Parkin, I. P.; Shearouse, W. C.; Steed, J. W.; Waddell, D. C. Chem. Soc. Rev. 2012, 41, 413-447. doi:10.1039/C1CS15171A

30. Margetić, D.; Štrukil, V. Mechanochemical Organic Synthesis; Elsevier: Boston, 2016; pp 323-342. doi:10.1016/B978-0-12-802184-2.00007-8

31. Takacs, L. Chem. Soc. Rev. 2013, 42, 7649-7659. doi:10.1039/c2cs35442j 
32. Ribas-Arino, J.; Marx, D. Chem. Rev. 2012, 112, 5412-5487. doi:10.1021/cr200399q

33. Šepelák, V.; Düvel, A.; Wilkening, M.; Becker, K.-D.; Heitjans, P. Chem. Soc. Rev. 2013, 42, 7507-7520. doi:10.1039/c2cs35462d

34. Braga, D.; Maini, L.; Grepioni, F. Chem. Soc. Rev. 2013, 42, 7638-7648. doi:10.1039/c3cs60014a

35. Groote, R.; van Haandel, L.; Sijbesma, R. P. J. Polym. Sci., Part A: Polym. Chem. 2012, 50, 4929-4935. doi:10.1002/pola.26323

36. Friščić, T. J. Mater. Chem. 2010, 20, 7599-7605. doi:10.1039/c0jm00872a

37. Haehnel, A. P.; Sagara, Y.; Simon, Y. C.; Weder, C. Top. Curr. Chem. 2015, 369, 345-375. doi:10.1007/128_2015_640

38. Toda, F.; Tanaka, K.; Iwata, S. J. Org. Chem. 1989, 54, 3007-3009. doi:10.1021/jo00274a007

39. Jörres, M.; Aceña, J. L.; Soloshonok, V. A.; Bolm, C. ChemCatChem 2015, 7, 1265-1269. doi:10.1002/cctc.201500102

40. Jacob, K.; Schmidt, R.; Stolle, A. Ball Milling Towards Green Synthesis: Applications, Projects, Challenges; The Royal Society of Chemistry, 2015; pp 34-57. doi:10.1039/9781782621980-00034

41. Tan, D.; Mottillo, C.; Katsenis, A. D.; Štrukil, V.; Friščić, T. Angew. Chem., Int. Ed. 2014, 53, 9321-9324. doi:10.1002/anie.201404120

42. Ranu, B. C.; Chatterjee, T.; Mukherjee, N. Ball Milling Towards Green Synthesis: Applications, Projects, Challenges; The Royal Society of Chemistry, 2015; pp 1-33. doi:10.1039/9781782621980-00001

43. Friščić, T. Ball Milling Towards Green Synthesis: Applications, Projects, Challenges; The Royal Society of Chemistry, 2015; pp 151-189. doi:10.1039/9781782621980-00151

44. Saunders, G. C.; Wehr-Candler, T. T. J. Fluorine Chem. 2013, 153, 162-164. doi:10.1016/j.jfluchem.2013.05.030

45. Margetić, D.; Štrukil, V. Mechanochemical Organic Synthesis; Elsevier: Boston, 2016; pp 55-139. doi:10.1016/B978-0-12-802184-2.00002-9

46. Margetić, D.; Štrukil, V. Mechanochemical Organic Synthesis; Elsevier: Boston, 2016; pp 293-321. doi:10.1016/B978-0-12-802184-2.00006-6

47. Margetić, D.; Štrukil, V. Mechanochemical Organic Synthesis; Elsevier: Boston, 2016; pp 283-292. doi:10.1016/B978-0-12-802184-2.00005-4

48. Raston, C. L.; Scott, J. L. Green Chem. 2000, 2, 49-52. doi:10.1039/A907688C

49. Guillena, G.; Hita, M. d. C.; Nájera, C.; Viózquez, S. F. J. Org. Chem. 2008, 73, 5933-5943. doi:10.1021/jo800773q

50. Machuca, E.; Juaristi, E. Tetrahedron Lett. 2015, 56, 1144-1148. doi:10.1016/j.tetlet.2015.01.079

51. Zhang, Z.; Dong, Y.-W.; Wang, G.-W.; Komatsu, K. Chem. Lett. 2004, 33, 168-169. doi:10.1246/cl.2004.168

52. Jörres, M.; Mersmann, S.; Raabe, G.; Bolm, C. Green Chem. 2013, 15, 612-616. doi:10.1039/c2gc36906k

53. Mack, J.; Shumba, M. Green Chem. 2007, 9, 328-330. doi:10.1039/B612983H

54. Balema, V. P.; Wiench, J. W.; Pruski, M.; Pecharsky, V. K. Chem. Commun. 2002, 724-725. doi:10.1039/B111515D

55. Balema, V. P.; Wiench, J. W.; Pruski, M.; Pecharsky, V. K. J. Am. Chem. Soc. 2002, 124, 6244-6245. doi:10.1021/ja017908p

56. Nielsen, S. F.; Peters, D.; Axelsson, O. Synth. Commun. 2000, 30 , 3501-3509. doi:10.1080/00397910008087262

57. Jiang, Z.-J.; Li, Z.-H.; Yu, J.-B.; Su, W.-K. J. Org. Chem. 2016, 81, 10049-10055. doi:10.1021/acs.joc.6b01938
58. Tullberg, E.; Schacher, F.; Peters, D.; Frejd, T. Synthesis 2006, 1183-1189. doi:10.1055/s-2006-926371

59. Zhu, X.; Liu, J.; Chen, T.; Su, W. Appl. Organomet. Chem. 2012, 26, 145-147. doi:10.1002/aoc.2827

60. Thorwirth, R.; Stolle, A.; Ondruschka, B. Green Chem. 2010, 12, 985-991. doi:10.1039/c000674b

61. Maiti, S.; Mal, P. Org. Lett. 2017, 19, 2454-2457. doi:10.1021/acs.orglett.7b01117

62. Maiti, S.; Achar, T. K.; Mal, P. Org. Lett. 2017, 19, 2006-2009. doi:10.1021/acs.orglett.7b00562

63. Girard, S. A.; Knauber, T.; Li, C.-J. From C-H to C-C Bonds: Cross-Dehydrogenative-Coupling; The Royal Society of Chemistry, 2015; pp 1-32. doi:10.1039/9781782620082-00001

64. Yeung, C. S.; Dong, V. M. Chem. Rev. 2011, 111, 1215-1292. doi:10.1021/cr100280d

65. Yoo, W.-J.; Li, C.-J. Top. Curr. Chem. 2010, 292, 281-302. doi:10.1007/128_2009_17

66. Li, C.-J. Acc. Chem. Res. 2009, 42, 335-344. doi:10.1021/ar800164n

67. Su, W.; Yu, J.; Li, Z.; Jiang, Z. J. Org. Chem. 2011, 76, 9144-9150. doi:10.1021/jo2015533

68. Yu, J.; Li, Z.; Jia, K.; Jiang, Z.; Liu, M.; Su, W. Tetrahedron Lett. 2013, 54, 2006-2009. doi:10.1016/j.tetlet.2013.02.007

69. Yu, J.-B.; Zhang, Y.; Jiang, Z.-J.; Su, W.-K. J. Org. Chem. 2016, 81, 11514-11520. doi:10.1021/acs.joc.6b02197

70. Jia, K.-Y.; Yu, J.-B.; Jiang, Z.-J.; Su, W.-K. J. Org. Chem. 2016, 81, 6049-6055. doi:10.1021/acs.joc.6b01138

71. Ruiz-Castillo, P.; Buchwald, S. L. Chem. Rev. 2016, 116, 12564-12649. doi:10.1021/acs.chemrev.6b00512

72. Fennie, M. W.; Roth, J. M. J. Chem. Educ. 2016, 93, 1788-1793. doi:10.1021/acs.jchemed.6b00090

73. Muñiz, K. Top. Curr. Chem. 2016, 373, 105-133. doi:10.1007/128_2015_663

74. Louillat, M.-L.; Patureau, F. W. Chem. Soc. Rev. 2014, 43, 901-910. doi:10.1039/C3CS60318K

75. Bariwal, J.; Van der Eycken, E. Chem. Soc. Rev. 2013, 42, 9283-9303. doi:10.1039/C3CS60228A

76. Schmidt, A. W.; Reddy, K. R.; Knölker, H.-J. Chem. Rev. 2012, 112, 3193-3328. doi:10.1021/cr200447s

77. Margetić, D.; Štrukil, V. Mechanochemical Organic Synthesis; Elsevier: Boston, 2016; pp 141-233. doi:10.1016/B978-0-12-802184-2.00003-0

78. Zhu, X.; Zhang, Q.; Su, W. RSC Adv. 2014, 4, 22775-22778. doi:10.1039/c4ra02952f

79. Achar, T. K.; Mal, P. J. Org. Chem. 2015, 80, 666-672. doi:10.1021/jo502464n

80. Achar, T. K.; Sahoo, P. K.; Mal, P. ChemistrySelect 2017, 2, 1944-1949. doi:10.1002/slct.201700210

81. Achar, T. K.; Mal, P. Adv. Synth. Catal. 2015, 357, 3977-3985. doi:10.1002/adsc.201500914

82. Alt, I. T.; Plietker, B. Angew. Chem., Int. Ed. 2016, 55, 1519-1522. doi:10.1002/anie.201510045

83. Antonchick, A. P.; Samanta, R.; Kulikov, K.; Lategahn, J. Angew. Chem., Int. Ed. 2011, 50, 8605-8608. doi:10.1002/anie.201102984

84. Camasso, N. M.; Sanford, M. S. Science 2015, 347, 1218-1220. doi:10.1126/science.aaa4526

85. Konnert, L.; Lamaty, F.; Martinez, J.; Colacino, E. J. Org. Chem. 2014, 79, 4008-4017. doi:10.1021/jo500463y

86. Jiang, D.; He, T.; Ma, L.; Wang, Z. RSC Adv. 2014, 4, 64936-64946. doi:10.1039/C4RA10784E 
87. Dokli, I.; Gredičak, M. Eur. J. Org. Chem. 2015, 2727-2732. doi:10.1002/ejoc.201500051

88. Bose, A.; Mal, P. Tetrahedron Lett. 2014, 55, 2154-2156. doi:10.1016/j.tetlet.2014.02.064

89. Margetić, D.; Štrukil, V. Mechanochemical Organic Synthesis; Elsevier: Boston, 2016; pp 235-282. doi:10.1016/B978-0-12-802184-2.00004-2

90. Waddell, D. C.; Thiel, I.; Bunger, A.; Nkata, D.; Maloney, A.; Clark, T.; Smith, B.; Mack, J. Green Chem. 2011, 13, 3156-3161. doi:10.1039/c1gc15594f

91. Chatterjee, T.; Saha, D.; Ranu, B. C. Tetrahedron Lett. 2012, 53, 4142-4144. doi:10.1016/j.tetlet.2012.05.127

92. Lanzillotto, M.; Konnert, L.; Lamaty, F.; Martinez, J.; Colacino, E. ACS Sustainable Chem. Eng. 2015, 3, 2882-2889. doi:10.1021/acssuschemeng.5b00819

93. Gribble, G. W. Acc. Chem. Res. 1998, 31, 141-152. doi:10.1021/ar9701777

94. Gribble, G. W. Chem. Soc. Rev. 1999, 28, 335-346. doi:10.1039/A900201D

95. Rahman, A. N. M. M.; Bishop, R.; Tan, R.; Shan, N. Green Chem. 2005, 7, 207-209. doi:10.1039/B416275G

96. Wang, G.-W.; Gao, J. Green Chem. 2012, 14, 1125-1131. doi:10.1039/c2gc16606b

97. Schmidt, R.; Stolle, A.; Ondruschka, B. Green Chem. 2012, 14, 1673-1679. doi:10.1039/c2gc16508b

98. Maiti, S.; Mal, P. Synth. Commun. 2014, 44, 3461-3469. doi:10.1080/00397911.2014.946995

99. Mendonça, G. F.; de Almeida, L. S.; de Mattos, M. C. S.; Esteves, P. M.; Ribeiro, R. S. Curr. Org. Synth. 2015, 12, 603-617. doi:10.2174/157017941205150821130712

100.Mishra, A. K.; Nagarajaiah, H.; Moorthy, J. N. Eur. J. Org. Chem. 2015, 2733-2738. doi:10.1002/ejoc.201403463

101.Nyffeler, P. T.; Durón, S. G.; Burkart, M. D.; Vincent, S. P.; Wong, C.-H. Angew. Chem., Int. Ed. 2004, 44, 192-212. doi:10.1002/anie.200400648

102. Howard, J. L.; Sagatov, Y.; Repusseau, L.; Schotten, C.; Browne, D. L. Green Chem. 2017, 19, 2798-2802. doi:10.1039/c6gc03139k

103.Brauch, S.; van Berkel, S. S.; Westermann, B. Chem. Soc. Rev. 2013, 42, 4948-4962. doi:10.1039/C3CS35505E

104.Eberlin, L.; Tripoteau, F.; Carreaux, F.; Whiting, A.; Carboni, B. Beilstein J. Org. Chem. 2014, 10, 237-250. doi:10.3762/bjoc.10.19

105.De, M. F.; Banfi, L.; Riva, R.; Basso, A. Comb. Chem. High Throughput Screening 2011, 14, 782-810. doi:10.2174/138620711796957099

106. Cho, H. Y.; Morken, J. P. Chem. Soc. Rev. 2014, 43, 4368-4380. doi:10.1039/c3cs60482a

107.Cores, A.; Carbajales, C.; Coelho, A. Curr. Top. Med. Chem. 2014, 14, 2209-2230. doi:10.2174/1568026614666141127115130

108.Ahmadi, T.; Ziarani, G. M.; Gholamzadeh, P.; Mollabagher, H. Tetrahedron: Asymmetry 2017, 28, 708-724. doi:10.1016/j.tetasy.2017.04.002

109.Dichtel, W. R.; Miljanić, O. Š.; Zhang, W.; Spruell, J. M.; Patel, K.; Aprahamian, I.; Heath, J. R.; Stoddart, J. F. Acc. Chem. Res. 2008, 41, 1750-1761. doi:10.1021/ar800067h

110. Miljanić, O. Š. Chem 2017, 2, 502-524. doi:10.1016/j.chempr.2017.03.002

111.Giri, C.; Sahoo, P. K.; Puttreddy, R.; Rissanen, K.; Mal, P. Chem. - Eur. J. 2015, 21, 6390-6393. doi:10.1002/chem.201500734
112. Haji, M. Beilstein J. Org. Chem. 2016, 12, 1269-1301. doi:10.3762/bjoc.12.121

113. Rotstein, B. H.; Zaretsky, S.; Rai, V.; Yudin, A. K. Chem. Rev. 2014, 114, 8323-8359. doi:10.1021/cr400615v

114.Koopmanschap, G.; Ruijter, E.; Orru, R. V. A. Beilstein J. Org. Chem. 2014, 10, 544-598. doi:10.3762/bjoc. 10.50

115. Kruithof, A.; Ruijter, E.; Orru, R. V. A. Chem. - Asian J. 2015, 10, 508-520. doi:10.1002/asia.201403207

116.Polindara-García, L. A.; Juaristi, E. Eur. J. Org. Chem. 2016, 1095-1102. doi:10.1002/ejoc.201501371

117.Liu, Y.-L.; Zhou, J. Synthesis 2015, 47, 1210-1226. doi:10.1055/s-0034-1380117

118.Cai, X.-H.; Xie, B. ARKIVOC 2014, 205-248. doi:10.3998/ark.5550190.p008.487

119.Sun, X.; Sun, Y.; Rao, Y. Curr. Org. Chem. 2016, 20, 1878-1901. doi:10.2174/1385272820666160331235519

120. Hernández, J. G.; Turberg, M.; Schiffers, I.; Bolm, C. Chem. - Eur. J. 2016, 22, 14513-14517. doi:10.1002/chem.201603057

121. Estévez, V.; Villacampa, M.; Menéndez, J. C. Chem. Commun. 2013, 49, 591-593. doi:10.1039/C2CC38099D

122. Tamaddon, F.; Moradi, S. J. Mol. Catal. A: Chem. 2013, 370, 117-122. doi:10.1016/j.molcata.2012.12.005

123. Trautwein, A. W.; Süßmuth, R. D.; Jung, G. Bioorg. Med. Chem. Lett. 1998, 8, 2381-2384. doi:10.1016/S0960-894X(98)00430-2

124.Suresh; Sandhu, J. S. ARKIVOC 2012, 66-133. doi:10.3998/ark.5550190.0013.103

125. Kappe, C. O. Acc. Chem. Res. 2000, 33, 879-888. doi:10.1021/ar000048h

126. Kaur, R.; Chaudhary, S.; Kumar, K.; Gupta, M. K.; Rawal, R. K. Eur. J. Med. Chem. 2017, 132, 108-134. doi:10.1016/j.ejmech.2017.03.025

127. Andraos, J. Beilstein J. Org. Chem. 2016, 12, 2420-2442. doi:10.3762/bjoc.12.236

128. de Fátima, Â.; Braga, T. C.; Neto, L. d. S.; Terra, B. S.; Oliveira, B. G. F.; da Silva, D. L.; Modolo, L. V. J. Adv. Res. 2015, 6 363-373. doi:10.1016/j.jare.2014.10.006

129. Kappe, C. O. Tetrahedron 1993, 49, 6937-6963. doi:10.1016/S0040-4020(01)87971-0

130. Nagarajaiah, H.; Mukhopadhyay, A.; Moorthy, J. N. Tetrahedron Lett. 2016, 57, 5135-5149. doi:10.1016/j.tetlet.2016.09.047

131. Castilla, A. M.; Ramsay, W. J.; Nitschke, J. R. Acc. Chem. Res. 2014, 47, 2063-2073. doi:10.1021/ar5000924

132. Nitschke, J. R. Acc. Chem. Res. 2007, 40, 103-112. doi:10.1021/ar068185n

133. Sahoo, P. K.; Bose, A.; Mal, P. Eur. J. Org. Chem. 2015, 6994-6998. doi:10.1002/ejoc.201501039

134.Li, Z.; Jiang, Z.; Su, W. Green Chem. 2015, 17, 2330-2334. doi:10.1039/c5gc00079c

135. Khan, M. M.; Khan, S.; Saigal; Iqbal, S. RSC Adv. 2016, 6, 42045-42061. doi:10.1039/c6ra06767k

136. Ruijter, E.; Scheffelaar, R.; Orru, R. V. A. Angew. Chem., Int. Ed. 2011, 50, 6234-6246. doi:10.1002/anie.201006515

137.Jiang, B.; Rajale, T.; Wever, W.; Tu, S.-J.; Li, G. Chem. - Asian J. 2010, 5, 2318-2335. doi:10.1002/asia.201000310

138. Estévez, V.; Villacampa, M.; Menéndez, J. C. Chem. Soc. Rev. 2014, 43, 4633-4657. doi:10.1039/C3CS60015G

139. Estévez, V.; Villacampa, M.; Menéndez, J. C. Chem. Soc. Rev. 2010, 39, 4402-4421. doi:10.1039/B917644F

140. Garbarino, S.; Ravelli, D.; Protti, S.; Basso, A. Angew. Chem., Int. Ed. 2016, 55, 15476-15484. doi:10.1002/anie.201605288 
141. Hügel, H. M. Molecules 2009, 14, 4936-4972. doi:10.3390/molecules 14124936

142.Akelis, L.; Rousseau, J.; Juskenas, R.; Dodonova, J.; Rousseau, C.; Menuel, S.; Prevost, D.; Tumkevičius, S.; Monflier, E.; Hapiot, F. Eur. J. Org. Chem. 2016, 31-35. doi:10.1002/ejoc.201501223

143.Mamada, M.; Pérez-Bolívar, C.; Kumaki, D.; Esipenko, N. A.; Tokito, S.; Anzenbacher, P., Jr. Chem. - Eur. J. 2014, 20, 11835-11846. doi:10.1002/chem.201403058

144.Alinezhad, H.; Salehian, F.; Biparva, P. Synth. Commun. 2012, 42, 102-108. doi:10.1080/00397911.2010.522294

145.Patil, M. R.; Yelamaggad, A.; Keri, R. S. Lett. Org. Chem. 2016, 13, 474-481. doi:10.2174/2212717803666160728170600

146. Sharma, H.; Singh, N.; Jang, D. O. Green Chem. 2014, 16, 4922-4930. doi:10.1039/c4gc01142b

147.Park, Y.; Kim, Y.; Chang, S. Chem. Rev. 2017, 117, 9247-9301. doi:10.1021/acs.chemrev.6b00644

148. Yang, Y.; Lan, J.; You, J. Chem. Rev. 2017, 117, 8787-8863. doi:10.1021/acs.chemrev.6b00567

149.Sharma, H.; Kaur, N.; Singh, N.; Jang, D. O. Green Chem. 2015, 17 , 4263-4270. doi:10.1039/c5gc00536a

150.Chavan, P. V.; Pandit, K. S.; Desai, U. V.; Wadgaonkar, P. P.; Nawale, L.; Bhansali, S.; Sarkar, D. Res. Chem. Intermed. 2017, 1-16. doi:10.1007/s11164-017-2955-y

151.Panda, S.; Maity, P.; Manna, D. Org. Lett. 2017, 19, 1534-1537. doi:10.1021/acs.orglett.7b00313

152. Mukherjee, N.; Ahammed, S.; Bhadra, S.; Ranu, B. C. Green Chem 2013, 15, 389-397. doi:10.1039/C2GC36521A

153. Tiwari, V. K.; Mishra, B. B.; Mishra, K. B.; Mishra, N.; Singh, A. S.; Chen, X. Chem. Rev. 2016, 116, 3086-3240. doi:10.1021/acs.chemrev.5b00408

154.Gaso-Sokac, D.; Stivojevic, M. Curr. Org. Chem. 2016, 20 , 2211-2221. doi:10.2174/1385272820666160215235852

155. Cook, T. L.; Walker, J. A., Jr.; Mack, J. Green Chem. 2013, 15, 617-619. doi:10.1039/c3gc36720g

156.Larock, R. C.; Yum, E. K.; Refvik, M. D. J. Org. Chem. 1998, 63 7652-7662. doi:10.1021/jo9803277

157.Zille, M.; Stolle, A.; Wild, A.; Schubert, U. S. RSC Adv. 2014, 4, 13126-13133. doi:10.1039/c4ra00715h

158.Dekamin, M. G.; Eslami, M. Green Chem. 2014, 16, 4914-4921. doi:10.1039/c4gc00411f

159. Omachi, H.; Segawa, Y.; Itami, K. Acc. Chem. Res. 2012, 45 , 1378-1389. doi:10.1021/ar300055x

160.Watanabe, M.; Chen, K.-Y.; Chang, Y. J.; Chow, T. J. Acc. Chem. Res. 2013, 46, 1606-1615. doi:10.1021/ar400002y

161.Usta, H.; Facchetti, A.; Marks, T. J. Acc. Chem. Res. 2011, 44, 501-510. doi:10.1021/ar200006r

162.Jiang, W.; Li, Y.; Wang, Z. Chem. Soc. Rev. 2013, 42, 6113-6127. doi:10.1039/c3cs60108k

163. Anthony, J. E. Chem. Rev. 2006, 106, 5028-5048. doi:10.1021/cr050966z

164. Mateo-Alonso, A. Chem. Soc. Rev. 2014, 43, 6311-6324. doi:10.1039/C4CS00119B

165.Bunz, U. H. F. Chem. - Eur. J. 2009, 15, 6780-6789. doi:10.1002/chem.200900990

166.Hsu, D.-T.; Lin, C.-H. J. Org. Chem. 2009, 74, 9180-9187. doi:10.1021/jo901754w

167.Hu, J.; Zhang, D.; Harris, F. W. J. Org. Chem. 2005, 70, 707-708. doi:10.1021/jo048509q

168.Lin, Y.-C.; Lin, C.-H.; Chen, C.-Y.; Sun, S.-S.; Pal, B. Org. Biomol. Chem. 2011, 9, 4507-4517. doi:10.1039/c0ob00575d
169.Sahoo, P. K.; Giri, C.; Haldar, T. S.; Puttreddy, R.; Rissanen, K.; Mal, P. Eur. J. Org. Chem. 2016, 1283-1291. doi:10.1002/ejoc.201690012

170.Li, L.; Wang, J.-J.; Wang, G.-W. J. Org. Chem. 2016, 81, 5433-5439. doi:10.1021/acs.joc.6b00786

171. Mukherjee, N.; Chatterjee, T.; Ranu, B. C. J. Org. Chem. 2013, 78, 11110-11114. doi:10.1021/jo402071b

172. Hernández, J. G.; Bolm, C. J. Org. Chem. 2017, 82, 4007-4019. doi:10.1021/acs.joc.6b02887

173.Adeyemi, O. G.; Coville, N. J. Organometallics 2003, 22, 2284-2290. doi:10.1021/om0301738

174. Volkov, V. V.; Myakishev, K. G. Inorg. Chim. Acta 1999, 289, 51-57. doi:10.1016/S0020-1693(99)00057-2

175. Hernández, J. G.; Macdonald, N. A. J.; Mottillo, C.; Butler, I. S.; Friščić, T. Green Chem. 2014, 16, 1087-1092. doi:10.1039/c3gc42104j

176. Hernández, J. G.; Butler, I. S.; Friščić, T. Chem. Sci. 2014, 5, 3576-3582. doi:10.1039/C4SC01252F

177.Egbert, J. D.; Slawin, A. M. Z.; Nolan, S. P. Organometallics 2013, 32, 2271-2274. doi:10.1021/om301187a

178. Juribašić, M.; Užarević, K.; Gracin, D.; Ćurić, M. Chem. Commun. 2014, 50, 10287-10290. doi:10.1039/c4cc04423a

179.Aleksanyan, D. V.; Churusova, S. G.; Aysin, R. R.; Klemenkova, Z. S.; Nelyubina, Y. V.; Kozlov, V. A. Inorg. Chem. Commun. 2017, 76, 33-35. doi:10.1016/j.inoche.2016.12.006

180. Rightmire, N. R.; Hanusa, T. P.; Rheingold, A. L. Organometallics 2014, 33, 5952-5955. doi:10.1021/om5009204

181.Do, J.-L.; Mottillo, C.; Tan, D.; Štrukil, V.; Friščić, T. J. Am. Chem. Soc. 2015, 137, 2476-2479. doi:10.1021/jacs.5b00151 182. Hermann, G. N.; Becker, P.; Bolm, C. Angew. Chem., Int. Ed. 2015, 54, 7414-7417. doi:10.1002/anie.201502536

183. Hermann, G. N.; Becker, P.; Bolm, C. Angew. Chem., Int. Ed. 2016, 55, 3781-3784. doi:10.1002/anie.201511689

184. Hernández, J. G.; Bolm, C. Chem. Commun. 2015, 51, 12582-12584. doi:10.1039/c5cc04423e

185.Lou, S.-J.; Mao, Y.-J.; Xu, D.-Q.; He, J.-Q.; Chen, Q.; Xu, Z.-Y. ACS Catal. 2016, 6, 3890-3894. doi:10.1021/acscatal.6b00861

186. Hermann, G. N.; Bolm, C. ACS Catal. 2017, 7, 4592-4596. doi:10.1021/acscatal.7b00582

187. Hermann, G. N.; Jung, C. L.; Bolm, C. Green Chem. 2017, 19, 2520-2523. doi:10.1039/c7gc00499k

188. Ladziata, U.; Zhdankin, V. V. ARKIVOC 2006, 26-58. doi:10.3998/ark.5550190.0007.903

189. Katritzky, A. R.; Khashab, N. M.; Bobrov, S.; Yoshioka, M. J. Org. Chem. 2006, 71, 6753-6758. doi:10.1021/jo060793t

190.Štrukil, V.; Gracin, D.; Magdysyuk, O. V.; Dinnebier, R. E.; Friščić, T. Angew. Chem., Int. Ed. 2015, 54, 8440-8443. doi:10.1002/anie.201502026 
Beilstein J. Org. Chem. 2017, 13, 1907-1931.

\section{License and Terms}

This is an Open Access article under the terms of the Creative Commons Attribution License

(http://creativecommons.org/licenses/by/4.0), which permits unrestricted use, distribution, and reproduction in any medium, provided the original work is properly cited.

The license is subject to the Beilstein Journal of Organic Chemistry terms and conditions:

(http://www.beilstein-journals.org/bjoc)

The definitive version of this article is the electronic one which can be found at:

doi:10.3762/bjoc. 13.186 